University of Massachusetts Amherst

ScholarWorks@UMass Amherst

Masters Theses 1911 - February 2014

1987

\title{
Eye movement guidance in reading :: the role of parafoveal letter and space information.
}

Robin K. Morris

University of Massachusetts Amherst

Follow this and additional works at: https://scholarworks.umass.edu/theses

Morris, Robin K., "Eye movement guidance in reading :: the role of parafoveal letter and space information." (1987). Masters Theses 1911 - February 2014. 2134.

Retrieved from https://scholarworks.umass.edu/theses/2134

This thesis is brought to you for free and open access by ScholarWorks@UMass Amherst. It has been accepted for inclusion in Masters Theses 1911 - February 2014 by an authorized administrator of ScholarWorks@UMass Amherst. For more information, please contact scholarworks@library.umass.edu. 


\title{
EYE MOVEMENT GUIDANCE IN READING
}

THE ROLE OF PARAFOVEAL LETTER AND SPACE INFORMATION

\section{A Thesis Presented}

By

ROBIN K. MORRIS

\begin{abstract}
Submitted to the Graduate School of the Universlty of Massachusetts In partial fulfillment of the requirement for the degree of MASTER OF SCIENCE
\end{abstract}

SEPTEMBER , 1987

Psychology 
EYE MOVEMENT GUIDANCE IN READING:

THE ROLE OF PARAFOVEAL LETTER AND SPACE INFORMATION

A Thesls Presented

By

RobIn K. Morr Is

Approved as to style and content by:

Hitt

Kelth Rayner, Chalrperson of Commlttee

Cilixandu Pillater

Alexander Pollatsek, Member
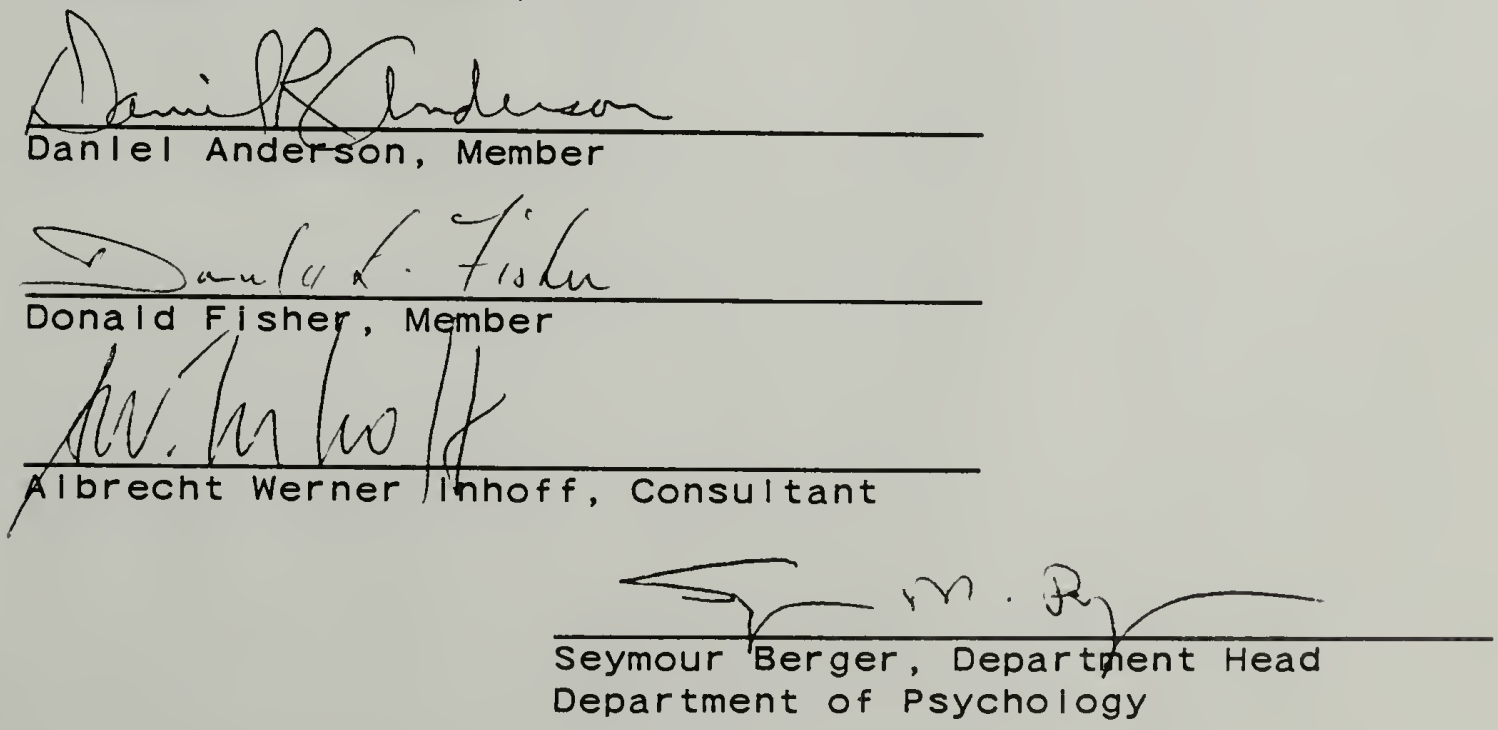


\section{TABLE OF CONTENTS}

LIST OF TABLES

LIST OF FIGURES

CHAPTER

I. INTRODUCTION

A Model of Saccade Programming

The Role of Attention In Reading. . . . . . . 2

The Role of Word Boundarles l. . . . . 7

The Role of Word Boundarles . . . . . . . . . 9

A Model of Eye Guldance . . . . . . . . . . : 11

11. EXPERIMENT 1 . . . . . . . . . . . . . . 13

Method . . . . . . . . . . . . . . . . . 19

Results and Discussion... . . . . . . . . . . 25

III. EXPERIMENT 2 . . . . . . . . . . . . . . 37

Method . . . . . . . . . . . . . . . 46

Results and DIscussion.......... . . . 48

IV. GENERAL DISCUSSION ............. 61

DIrect Control of Two Independent Processes . 62 Role of Word Boundary Information ... . . . 64

The Role of Attention In Eye Guldance. . . 71

OutI Ine for an Eye Guldance Model. . . . . 74

APPENDIX . . . . . . . . . . . . . . 81

BIBLIOGRAPHY . . . . . . . . . . . 102 


\section{TABLES}

Table

1a. Landing Position with First Space Open In Exper Iment 2. . . . . . . . . . . . 58

1b. Landing Position with First space Filled in Exper Iment 2 . . . . . . . . . . . . 58

2a. Landing Frequency with Flrst space Open in

Exper Iment 2. . . . . . . . . . . . . . . . . . 60

2b. Landing Frequency with FIrst space FIIled In Experiment 2. . . . . . . . . . . 60 


\section{FIGURES}

\section{Figure}

1. Reading Rate. . . . . . . . . . . . 82

2. Fixation Duration .......... . . . . 83

3. Saccade Length . . . . . . . . . . . . 84

4. Word Sklpping . . . . . . . . . . . . . . 85

5. Consecutive refixations... . . . . . . . . 86

6. Reading Rate............. . . . 87

7. Fixation Duration . . . . . . . . . . . . 88

8. Saccade Length . . . . . . . . . . . . 89

9. Word Sklppling . . . . . . . . . . . . . . 90

10. Consecutive refixations . . . . . . . . . . . . . 91 


\section{H A P T E R I}

\section{INTRODUCTION}

There is a considerable body of data in the I Iterature on eye movement control in reading that shows a close relationship between visual character Istics of the text and the pattern of fixations. This relationshlp is evident from the fact that word length patterns in the text are related to where the reader fixates next. If the word to the right of fixation is long the amplitude of the saccade tends to be greater than If the word is short (Rayner, 1979). If a word of three letters or less is immediately to the right of fixation there is a high probablilty It wIII be skipped (Rayner, 1979). In addition, the location of fixations within a word is not random; there is a preferred location between the first and middle letters of a word (O'Regan, 1981 ; Rayner, 1979).

All these pleces of evidence polnt to the conciusion that the decision of where to move the eye next is not made on a random basis. There is also now falriy substantial evidence to Indlcate that gross visual characterlstics of the text in the parafovea to the right of fixation influence the location of the next fixation. In particular, it seems clear that word length is a factor in determining where the eye wIII land. However, it remalns unclear at this point what the separate effects of letter and space information are, and how they interact with one another in the process 
of programming a saccade. Before looking more closely at what kind of Information is utilized to program a saccade let us turn to a model of when and how the programming of a movement could occur.

\section{A Model Of Saccade ProgrammIng}

To what extent are eye movement declslons under the direct control of the reader? That is, can these decislons be made on the basls of Information recelved In the course of a single fixation (direct control), or must some decislons be made In advance and then held in a buffer until the approprlate time to execute them (preprogramming)? Second, what might the process of programming these movements look I Ike?

Rayner and Pollatsek (1981) Investigated the flrst question by manlpulating the slze of an eye contingent "wIndow" of readable text elther in fixed blocks or varled randomily from fixation to fixation. Earlier studles (McConkle \& Rayner, 1975; Rayner, Inhoff, Morrison, Slowlaczek, \& Bertera, 1981) had shown that the length of the saccade Increased as the slze of the wIndow Increased. Rayner and Pollatsek reasoned that If eye movement declslons are under direct control (I.e., declsions are made within an individual fixation), parameters such as saccade length should be affected equaliy in the two conditions. On the 
other hand, if only delayed control is posslble, or if saccade length is preprogrammed ( $1 . e$. , the saccade is programmed on the prevlous fixation and held in a buffer), then it could not change as a function of window size in the varlable condition. The data showed that saccade length varled with window size almost identically in both conditions. However, further analyses Indlcated that there was also a small effect of the size of the window on the previous fixation.

Rayner and Pollatsek (1981) also created a stimulus onset delay by means of an eye contingent mask that was presented fovealiy at the beginning of a flxation and then removed after some time to reveal the text. As before, trlais were elther blocked or random. In general, flxation duration Increased by an amount nearly equal to the delay of the text In both conditions. For the most part subjects simply walted out the mask on each fixation and programmed thelr eye movements only after there was sufflclent Information avaliable to process the current fixation.

However, this is a complete plcture only at short delays. When stimulus onset delays were extended to 200-300 ms, Rayner and Pollatsek reported evldence suggesting that preprogramming of saccades may occur. That is, a saccade would be programmed on flxation $n$, held In a buffer, and then executed to terminate fixation $n+1$. The eyes sometimes moved before the delay perlod ended, without ever having 
seen the text. These saccades and the flxations they terminate were termed "anticlpations", and they contrlbuted to a blmodal distribution of fixation duration. To account for thelr data, Rayner and Pollatsek proposed a mlxed control model in which most decisions are made based on Information recelved within that fixation; preprogramming occurred on exceptional occaslons. However, these data could also be explalned by a model whlch Included parallel programming of saccades (Becker \& Jurgens,1979; Morr Ison, 1984).

Becker and Jurgens (1979) used a double-step paradigm to demonstrate the phenomenon of parallel programming of saccades In response to simple stimull. Subjects were asked to flxate a slngle target and track any change of location of the target with thelr eyes. As the subject flxated the target It Jumped to a different location, and then agaln to a second new location. By varylng the delay between the first and second Jump of the target they obtalned data show Ing a varlety of patterns of saccades: two Independent saccades whlch mImlcked the two steps of the target, a single saccade to some Intermedlate location between the first and second target position, or a single saccade that sklpped the first location entIrely and landed on the second target position.

Perhaps the clearest evldence of parallel programming Is the case In which there was an extremely short fixation 
on the first target location terminated by a saccade to the second target location. The saccade to the second target location could not have been preprogrammed since the second target location was not known early enough for that to be possible. The saccade could not have been programmed during the fixation on the first location since that fixation was extremely short. Becker and Jurgens reasoned that the saccades may have been programmed in parallel if the programming conslsted of two stages; a computation stage and an execution stage. When two responses compete for the same stage of programming they interact with one another and the end result may be a saccade to some intermediate location between the first and second target steps. If two responses are separated by enough time that they do not compete for the same stage then they wIll be Independent. Thus, an extremely short fixation on the first target step reflects a brlef $t$ Ime between the programming of two eye movements, not an extremely fast latency for the second one.

However, reading is not directiy analogous to the Isolated target location task employed in Becker and Jurgens' double-step experiments. Reading is much more complex, both in terms of stimulus complexity and cognitive processing load. For this reason it is not necessarliy the case that the Becker and Jurgens model is adequate to descrlbe the saccadlc system as it operates in reading.

Morrison (1984) conducted a reading study which 
provided evidence that anticlpation eye movements I lke those reported by Rayner and Pollatsek (1981) can be explalned by a Darallel programming model very simllar to that of Becker and Jurgens. In Morrison's experlment (as in Rayner \& Pollatsek, 1981) an eye contingent foveal mask was used to delay the onset of the stimulus in each fixation. The duration of the delay was agaln manlpulated elther in fixed or randomlzed blocks. Morrison extended the delay conditions to Include delays of up to $300 \mathrm{~ms}$ in the random delay conditions. This is something that had not been done In the Rayner and Pollatsek (1981) study.

Although the length of the text delay strongly affected flxation duration, there was no difference in flxation durations between the flxed and randomized presentation conditions. Thls repllcated the Rayner and Pollatsek (1981) finding that fixation duration is under direct control. However, as with Rayner and Pollatsek (1981), not all flxatlons were lengthened by the perlod of the delay. Some flxations ended whlle the mask was stIII present, suggesting that the saccade terminating that fixation had been preprogrammed. But these antlclpation saccades could not have been completely determined before the flxation was processed because thelr length and the duration of the prlor flxation were affected by the spatlal extent of the mask (whlch varled randomly). Nelther preprogramming nor exlsting serlal control models of eye movement guldance 
could adequately account for these data. Thus, Morrison posited a direct control model, In which saccades could be programmed in parallel, to account for the data.

$$
\text { Morrison's model does not stipulate what }
$$

characterlstics of the display are used to determine the Intended landing position of the eye, nor does it define how different sources of information might interact. It does, however, contain some strong assumptions about the role attention plays in the reading process.

\section{The Role of AttentIon In Reading}

The concept of attention and its relation to eye movements had been curlously absent from models of eye control In reading untIl an article by Mcconkle appeared in 1979. Apparentiy, up unt I I that time, It was thought that Visual attention and eye position were redundant in reading, although several studies demonstrated that spatlal attention can be dissoclated from eye position In other tasks (Kaufman \& Rlchards, $1969 ;$ Engel, 1971).

McConkle (1979) suggested that spatlal attention shifts discretely across the text, and that these shifts of attention trigger eye movements in a serlal fashion. Morrison's model assumes that whlle attention sinlfts serlally word by word across the text saccades may be programmed In parallel. When shlfts of Internal spatlal 
attention exceed threshold there is an irrevocable committment to an eye movement in that direction. That is, the eyes move to where internal attention has already been, or shifts of attention preceed eye movements.

Morrison's model also assumes multiple shifts of attention can occur within the same flxation, without walting for feedback from earlier attention shifts. This suggests that If the reader continued to monltor parafoveal information even after the next movement was programmed he or she would have the potential to alter the subsequent landing position based on more slowiy processed, or late arriving, Information. This model does not stipulate how the Intended location of the movement is determined. That is, what information is used to make this decision?

According to the evidence presented thus far, we have a falr sketch of how the reader might guide hls or her eyes across the text. The reader fixates a word, encodes that word, shifts attention to the right, and inltiates the programming of a saccade to follow the shift of attention. More than one shift of attention may occur in the course of a single flxation and this would result in the initiation of a second motor program. The extent to which these programs overlap will determine the outcome in much the same way that Becker \& Jurgens (1979) descrlbed the programming of movements to simple stimuil. Now, the question remains, what characteristics of the text are utilized in this 
process, and when?

\section{The Role Of Word Boundarles}

There are at least two ways to look at the effect of word boundary information on the programming of saccades. One is to examine the position of fixations within words relative to the word's length. Another way of stating this would be: do readers land on systematlcally different letter positions within words of differing lengths? An alternative is to look at average saccade length (1.e., to look at changes in average saccade length based on the avallabllity of space Information).

Rayner \& McConkle (1976) Investigated the relationshlp between the number of letters in a word and the position in the word that the reader flxates. They computed the probablilty of a fixation landing on words of different lengths and the probablilty of flxating a letter position within a word of a given length. They found that as word length Increased, the probabllity of flxating the word Increased. However, even a random sequence of fixations would produce this result. The more Interesting finding was that a letter in a word four to seven letters long was more I Ikely to be fixated than a letter in a longer or a shorter word. This is partlaliy due to the fact that shorter words tend to be sklpped more often than do longer words (O'Regan, 
1979; Rayner, 1979).

More evidence polnting to the fact that the locations of fixations within words is not random comes from the preferred viewing location studies (Rayner, 1979; O'Regan, 1981). Both researchers found that readers tend to fixate between the first and middle letters of words. Rayner termed this the "preferred vlewing location". O'Regan's data Indicated a location more closely approximating the middle letter of the word, and he termed this the "convenlent vlewing position". The differences between the two are minor, and it seems reasonable to conclude that readers systematically flxate somewhere between the beginning and $\mathrm{mlddle}$ of words.

Pollatsek and Rayner (1982) conducted a serles of experiments to Investigate the role of word boundary Information in reading by evaluating changes in average saccade length. In these experlments, spaces between words were fllied contingent upon the reader's fixation. There were three conditions: all spaces to the right of fixation fllled, all spaces to the right of fixation except the first fllied, or only the first space to the right of fixation fllled. The space between the currentiy fixated word and the first word to the right of $\mid t$ wIII be referred to throughout thls paper as the "fIrst space". Several space-flliling characters were used: random letters, random numbers, or gratings. In addition, the time in the fixation when the 
space fliler appeared was varled from $0-150 \mathrm{~ms}$. In the conditions in which the first space was preserved the spacefll liers had no effect if they were delayed more than 50 ms and there was very littie difference in the amount of Interference across the varlous types of space fillers. In those conditions in which the first space was filled, fIIIIng the spaces produced Interference at all delays, and letters were more confusing than digits or gratings.

Pollatsek and Rayner's results support a two-process direct control model in which encoding of sufficient visual information to program the next saccade can occur within the first 50-75 $\mathrm{ms}$ of a fixation, and In which the processes which determine when to move and where to move are affected differentiy. FIIIIng parafoveal spaces disrupts the guldance of the next eye movement, whlle fll Ing foveal spaces (I.e., the first space) disrupts the processing of the fixated word as well. Since these manipulations affected average saccade length and flxation duration Independentiy, they provide additional support for the clalm made earlier by Rayner \& McConkle (1976), that declslons of where to move and when to move are made Independently.

\section{A Model Of Eye Guldance}

Now let us put this evidence together into a single model of eye guldance in reading. The assumptions of the 
model are falriy stralght forward: a) attention shifts when foveal processing of the currentiy fixated word is complete; b) attention moves forward word by word; c) eye movements follow these shifts of attention; d) more than one shift of attention can occur in the course of a single fixation; later eye movement programs can cancel or modify earlier ones; f) the landing position of a saccade can be computed before the decision to execute the saccade; g) the landing position of a saccade is calculated on the basis of word boundary information; $h$ ) decislons of where to move and when to move are independent of one another.

The key questlons to be addressed here relate to the role of parafoveal letter and space information, and the role of attention. Are saccades programmed solely on the basls of word length information, or does parafoveal letter Information Influence the decision of where to move? Does attention move serlaliy word by word? What prompts these shlfts of attention, and when do these things occur? Does the reader attend to parafoveal information throughout the duration of a fixation and utilize the additional Information to update their eye movement decisions? 


\section{H A P T E R II}

\section{EXPERIMENT 1}

This experiment was designed to investigate an assumption of the model presented previously. That is, are saccades programmed solely on the basis of word boundary Information, or does parafoveal letter Information play a role as well? If letter information does have an effect on the programming of saccades, how do these two sources of Information Interact; and when In the course of a fixation can these decisions be made? This experlment was carried out using the "moving window" technique developed by McConkle \& Rayner (1975). Readers were free to move their eyes whenever and wherever they wished, but the amount of useful information avaliable on each flxation was controlied by the experlmenter. Each time the reader moved $h / s$ or her eyes, a new reglon of text was exposed and another mutilated. This exposure or mutilation of information was controlled to occur at the onset of a flxation, or at one of several exper Imentaliy determined delays.

In the present experiment, elther word boundary or parafoveal letter Information to the right of fixation, was delayed. In all cases, a mask made of a "square wave grating", was used to obscure parafoveal information to the right of the currently flxated word. The word the reader was currently fixating and ali Information to the left of 
that word was always avallable. If the reader made a regressive movement the mask followed the eyes to the new location, cover Ing the Information the reader had just left. FIve delay condltions were employed: the parafoveal mask was I Ifted elther $0,50,150$, or $250 \mathrm{~ms}$, after the beginning of a fIxation or not at alI (InfInIte delay). If the relevant Information can be used throughout the duration of a flxation, then even when that Information is not aval Iable untII late In the fIxation It may stIII affect the pattern of when the eyes move and where they $I$ and.

The type of Information InItially avaliable in the parafovea was systematically manipulated In order to test the nature of the relationship between word boundary Information In the parafovea and the pattern of fixations. There were three parafoveal mask condltions consldered.

In the Letters Released (LR) conditlon word boundary Information remalned Intact. A parafoveal mask of gratings was used to cover the letters. After a delay perlod the letter Information was released. An example of a two flxation sequence us Ing a delay of $150 \mathrm{~ms} m$ Ight look l Ike the following (gratings are represented as $x$ 's In all examp les ) :

The cat $x \times x \times x \quad x \times x x \quad x \times x \quad x \times x \times x x \quad x x \quad x x x x$. (onset of f (xation)

The cat drank from the saucer of ml lk. (150 ms later)

The cat drank $x \times x \times \quad x \times x \quad x \times x \times x \times \quad x \times \quad x \times x x$. (new flxation) 
The dot Indicates the position of the current fixation.

The model presented in the Introduction predicts that the data from this condition would most closely approximate normal saccade length data, since the assumption is that saccades are programmed solely on the basis of word boundary information and that information was avaliable from the onset of the fixation in this condition. If the assumption that when and where to move are independent decisions is correct, then fixation durations could increase as delay increases in this condition due to the lack of parafoveal preview of letter information without affecting the saccade length data.

In the Spaces Released (SR) condition everything to the right of the currently fixated word was masked with gratings. At the approprlate onset $t$ ime, word length information was released and the letters remalned masked unt II they were brought into foveal vision.

A typical two fixation sequence looked I Ike this:

The cat $x \times x \times x \times x \times x \times x \times x \times x \times x \times x \times x \times x \times x \times x \times x \times$ (onset of f(xation)

The cat $x \times x \times x \quad x \times x x \quad x \times x \quad x \times x \times x \times \quad x \times \quad x \times x x$ (50 ms later)

The cat drankx $x \times x \times x \times x \times x \times x \times x \times x \times x \times x \times x \times x$ (new fixation)

In this case no information other than word length was released to the reader until the word was flxated. Therefore any effect on saccade length found in this condition could reasonably be attributed to the impact of 
word boundary Information on the programming of saccades. The model predicts that saccade length should decrease as delay increases in this condition. If it is the case that space Information can be attended to throughout the course of a fixation and that the late arriving Information can be used to modify movement programs, then there could be a beneflt even at the $250 \mathrm{~ms}$ delay, relative to the complete mask condition (Infinlte delay).

In the Letters and Spaces Released (LSR) condition everything to the right of fixation was masked with gratings. After some perlod of $t$ Ime parafoveal letter and space Information was released to the end of the IIne of text. The following is an example of a two fixation sequence in the Letters and Spaces Released condltion with a $50 \mathrm{~ms}$ delay:

The cat $x \times x \times x \times x \times x \times x \times x \times x \times x \times x \times x \times x \times x \times x \times x \times$ (onset of f (xation)

The cat drank from the saucer of $\mathrm{mllk}$. (50 $\mathrm{ms}$ later)

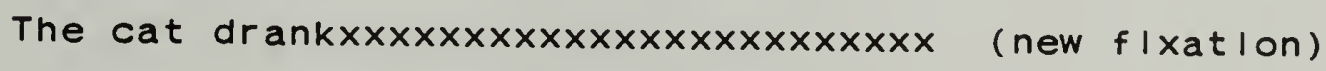

In this case the model predicts that the average saccade length should be no different than in the prevlous condition (SR). The release of word boundary informat ion is Identical in the two conditions. Thus, the fact that letter Information is released in this condition and not in the Spaces Released condition should have no Impact on the programming of the saccades. However, the flxation duration 
data should more closely approximate the Letters Released condition data since the assumption is that the decision of when to move is more strongly affected by letter Information, and both of these conditlons release letters.

Note that the first and the third conditlons provlded normal reading conditions at the 0 delay Interval, and that the second and third conditions provlded no parafoveal Information at the Infinite delay. Thus the zero and Infinite delay conditions provide useful baseline Information for comparison purposes.

Finaliy, the extent of the Information avaliable at the onset of a fixation was varled by IImItIng the slze of the InItlal window of readable text to elther one or two words from the point of fixation. In the One Word WIndow condition (1WW) parafoveal masking began on the word Immedlately to the right of the currently flxated word (word $n+1)$. Conditions whlch masked space information began on the space between word $n$ and word $n+1$. The prevlous examples and the predictions that followed were representative of the IWW case.

In the Two Word WIndow condition word $n$ and word $n+1$ were avallable to the reader at the onset of each fixation. The parafoveal mask began on word $n+2$, or on the space between word $n+1$ and word $n+2$. Examples of this condition would look like the prevlous examples if the reader was flxating the word Immedlately preceeding the dotted word. 
Large numbers of studies (McConkle \& Rayner, 1975 ; Ikeda \& Salda, 1978; Rayner \& Bertera, 1981; O'Regan, 1980; McConkle \& Rayner, 1976; Rayner, et al, 1981; Rayner, Well \& Pollatsek, 1980) using the moving window technique have found that the perceptual span extends from the beginning of the currentiy flxated word (no more than three to four characters to the left of fixation) to about 15 characters to the right of flxation. Within the perceptual span region to the right of fixation, different types of Information are acquired (Rayner, 1975; Rayner \& Mcconkle, 1977). It appears that readers obtain information useful for directly Identifying a word when it is in foveal vision or Just to the right of It. Beyond that area, readers are able to obtain some letter feature information. But the area from which they are able to obtain this information is less than 12 character spaces to the Irght of fixation. Word length Information is acquired from a silghtly larger region, approximately 15 character spaces to the right of fixation.

Although the approprlate unit of measure for the perceptual span to the right of fixation appears to be character spaces, rather than number of words (Rayner, Well, Pollatsek \& Bertera, 1982), it is true that in most cases the IImit of the perceptual span for letters is contalned within the boundary of a two word window to the right of fixation. Thus, the expectation was that there would be I ittle or no effect of letter releasing conditions in the 
2WW session of this experiment, since most usable Information would have been avaliable from the onset of the flxation. Because the perceptual span for space information Is somewhat larger than the span for letters there are more occasions in which the space information beyond the two word window could potentlaliy be utlilzed. Therefore an effect of releasing space information on the saccade length data would not be surprising. However, any effects found in the 2WW session should of a markedly smaller magnitude than those found in the 1WW session.

The design of the experiment consisted of five (delay) by three (parafoveal mask) by two (window) condltions. It was deslgned to address the extent to which parafoveal word boundary information is used to guide eye movements in reading.

\section{Method}

Subjects. The subjects in the experiment were 14 pald volunteers from the University of Massachusetts. subjects had previously particlpated in eye movement experiments and were native English speakers with uncorrected vision.

Apparatus. The sentences were displayed on a HewlettPackard 1300-A cathode ray tube (CRT). The CRT has a P-31 
phosphor with the characteristlc that removing a character resulted In a drop to $1 \%$ of maximum brightness in 0.25 ms. The letters making up the sentences were printed in lower case on the CRT. Each letter was made up of dots from a $5 \times$ 7 matrix. A black theater gel covered the CRT so that the letters and the mask appeared clear and sharp to the subjects. The visual mask consisted of an "Interlaced square wave grat Ing".

Eye movement recording was accomplished by using a Stanford Research Institute Dual-Purkinje Eyetracker (Clark, 1975; Cornsweet \& Crane, 1973). The eyetracker has a resolution of $10 \mathrm{~m}$ Inutes of arc, and the output is linear over the visual angle $(14)$ that was occupled by the sentences. The eyetracker and the CRT were Interfaced to a Hewlett-Packard 2100 computer that controlled the experiment. The signal from the eyetracker was sampled every mlilisecond by the computer through an A-D converter. Over each $4 \mathrm{~ms}$, the horlzontal voltage level was compared to the prior $4 \mathrm{~ms}$, and as the result of these values, the computer determined whether the eye was in a saccade or flxation. Our calculations and photoelectrlc testing have Indicated that the dIsplay change can be accomplished wIthIn 2-7 ms after the termination of the saccade. This value Includes the time for the computer to determine the new location of the eye, the lag in the signal from the eyetracker to the computer (about $1 \mathrm{~ms}$ ), and the time to 
output the mask to the CRT. In the experiment, the subject's eye was approximately $46 \mathrm{~cm}$ from the CRT, and three characters were equal to 1 of visual angle. Eye movements were monltored from the rlght eye, and view Ing was blnocular. The room was dark, except for a dim, indirect light source. The CRT was adjusted to a comfortable brightness for each subject (approximately $8 \mathrm{~cd} / \mathrm{m}$ as measured by a Tektronics $J 16$ photometer for three characters directly in front of the IumInance probe) and the Iuminance was occasionally reduced because of puplliary responses when the masks appeared. Puplilary constrictions and bilnks resulted in a track loss for the eye tracker, hence the reduction in iuminance. Sentences in which there was a track loss (In whlch case the mask did not move with the eye) were discarded from later data analysis.

The computer kept a complete record of the duration, sequence, and location of each eye fixation. These values were stored on the computer disk for later analysis.

StImull. Twenty-elght passages, elght sentences long, were written for thls experiment (see Appendlx B). Each sentence was flve to elght words in length, spanning no more than the 42 character spaces per I Ine allowed by our equlpment. The passages were presented to the reader one line at a time. Stimuius materiais were created as sets of related text, rather than single sentences, to keep readers motivated to 
read for comprehension.

Comprehension questions which required a yes/no response from the reader were created for each story. Questions were asked only at the end of a passage to encourage active Integration of the Information on the part of the reader in order to answer the question correctly. A yes/no response could be made wlthout leavling the bite bar and thereby simplifled the experimental procedure. Comprehension questions also allowed a check on performance across all condltions to verlfy that subjects were acquiring the meaning of the text under all parafoveal manipulations and delays. Subjects responded correctly approximately $90 \%$ of the $t$ Ime.

Procedure. When the subject arrlved for the experlment a blte bar was prepared which served to ellminate head movements during the experiment. Then the eye movement recording system was callbrated for the subject. Callbration was achleved by having the subject flxate on a target presented successively on the left and then on the right of the display. The target cross remalned in each position for 1 second, and the eye position was sampled over the final $500 \mathrm{~ms}$. The subject was asked to flxate the left cross and then to move his/her eyes to the rlght and flxate the right target position when the cross disappeared from the left and reappeared on the rlght of the display. Next the calibration target on the rlght disappeared and three 
crosses appeared simultaneously to the left, to the right, and in the center of the display, equldistance apart. The subject was then asked to fixate the center cross and a fourth cross moving in synchrony with the eye was observed by the experimenter. If the cross was super imposed over the center cross the callibration process was consldered complete and the experimenter proceded with the experiment. If the cross was not superimposed on the center target the callibration process was repeated. Since all subjects were experlenced In this procedure, InItlal callbration took less than five minutes in most cases.

After the InIt|al callbration, subjects were Instructed to look to the left slde of the display when they were ready to read. The experimenter then pushed a button to display the stimulus sentence. Subjects were told to read the sentence and press a key when they were finIshed. When the key was pressed the sentence disappeared and the target crosses appeared to the left and right of the display for callibration checking. The next sentence was presented Immedlately following the callbration check.

All subjects were told at the beginning of the experiment, that they would be reading short passages, each one separated by the heading "new paragraph", and that varlous aspects of the information to the right of fixation would be masked in some cases. Thelr task was to read the passage to understand $1 t$ and to answer comprehension 
questlons at the end of some passages.

The experiment was divided Into two sessions, with a 10-15 minute break between sessions. Each session began with elght practice sentences that were representative of the mask manipulations contalned in that session. Upon completion of the practice sentences each subject read 14 experlmental passages. Comprehenslon questlons were asked after every second story on the average. ThIs procedure was repeated for the second session.

Experlmental Deslgn. During the reading of the experimental passages, the parafoveal mask was manlpulated contingent upon the reader's eye position. In one session all parafoveal masking began with the space Immedlately to the right of the currently flxated word and extended to the end of the I Ine of text. In the other session the mask began on the space Immedlately to the $r$ lght of word $n+1$. These conditions, as Indlcated earller, wIII be refered to as one Word WIndow and Two Word WIndow, respectlvely. The order of presentation of these sesslons was counterbalanced across subjects.

The three parafoveal mask conditlons (Letters and Spaces Released, Letters Released, Spaces Released) by flve delay conditions $(0,50,150,250$, InfInIte) ylelded a total of 15 possible comblnations. However, since the Letters and Spaces Released condition and the Letters Released condition 
both resulted in a normal reading condition at the 0 delay Interval, these two cells were reduced to one. There were a total of 14 conditions within each session. Each condition was presented for one elght sentence block.

One session conslsted of one window condition, with the order of three parafoveal mask by flve delay conditions (minus 1) partially counterbalanced across the 14 subjects. The counterbalancing of parafoveal mask by delay was completed across the two sessions.

\section{Results and DIscussion}

For each subject, reading performance was assessed by the average reading rate, in words per minute (wpm), and by other more detalled analyses: the average length of a forward saccade (measured in character spaces), the average duration of a fixation (measured in ms), the average number of occurrences per I Ine of two consecutive forward fixations on the same word (consecutive fixatlons), and the average number of times per IIne a forward saccade resulted in the sklpping of word $n+1$ glven the reader had $f(x a t e d$ word $n$ and word $n+2$ consecut I vely (word skipplng).

For each data set a 2 (wIndow slze) $\times 3$ (parafoveal mask) $x 3$ (delay) ANOVA was done on all the data except the control conditions. However, for purposes of comparison, the control conditions are Included in the figures. In addition 
to the overall analyses, a separate 3 (parafoveal mask) $x$ 3 (delay) ANOVA was performed on the data from each session, and In some cases post hoc comparisons were done to clarify relevant polnts. These are specifled in thelr respective sections.

Reading rate. The 2 (w Indow $s \mid z e) \times 3$ (parafoveal mask) $\times$ 3 (delay) ANOVA of the reading rate data ylelded clear effects of wIndow slze, $F(1,13)=26.84, p<.001$; parafoveal mask, $F(2,26)=18.12, p<.00001$; and delay, $F(2,26)=14.17$, $\mathrm{p}<.001$. There was also an Interaction of $w I n d o w s \mid z e$ and delay, $F(2,26)=3.56, p<.05$. In the Two Word WIndow session delay had virtually no effect, whlle in the One Word Window session reading rate decreased as delay Increased. Separate analyses of each window slze session suggests that most of the Impact of these effects occurs in the One Word WIndow session (see below).

An ANOVA done on the data from the Two Word WIndow sesslon ylelded no signiflcant overall effects. However, an ANOVA of the Letters Released versus the Spaces Released condition was signiflcant, $F(1,13)=4.45, p<.05$. Reading speed was faster when there was parafoveal preview of letter Information, glven that space information was avallable from the onset of the fIxation.

In contrast, a $3 \times 3$ ANOVA on the data from the One Word WIndow session Indlcated clear effects of parafoveal mask, 
$F(2,26)=19.11, p<.0001$, and delay, $F(2,26)=25.32, p<.0001$. There was also an Interaction between the type of Information avallable parafoveally and when that information was present, $F(4,52)=5.97, p<.001$. The release of letter Information had no effect beyond that of space information released alone after $50 \mathrm{~ms}$, whlle the two condltions whlch delayed release of space Information continued to deciline across delays of up to $250 \mathrm{~ms}$. Thls Interaction suggests that parafoveal letter Information may be helpful only if it Is avallable very early in a fixation.

Is there continuous processing of parafoveal Information beyond the $50-75 \mathrm{~ms}$ normally used to extract the Information to program a saccade (see Pollatsek \& Rayner, 1982)? The curves decreased as the delay of parafoveal Information Increased, up to the polnt where no parafoveal Information was released at all In the One Word WIndow session (see the rlght panel of Flg.1). Some aspects of the parafoveal Information were utllized In reading, even when delayed as much as $250 \mathrm{~ms}$. But In general, the longer the delay Interval was, the smaller the beneflt. The type of Information belng utIllzed wIII be addressed In more detall later In this paper.

Reading rate is a global measure of reading performance. These data Indlcated that (1) letter and space Information In the parafovea may play different roles, at different $t$ Imes in the reading process, (2) manipulation of 
parafoveal Information beyond word $n+1$ has little to no effect on reading rate, and (3) some parafoveal information presented late in a fixation can be utIIIzed. We can not Interpret from these data whlch aspects of parafoveal Information are Influencing the computation of saccades (where to move), and whlch are influenclng processing of the currently flxated word (when to move). We must examine more specific measures in order to construct a more detalled Interpretation.

FIxation duration. A $2 \times 3 \times 3$ ANOVA of the fixation duration data Indicated that fixation durations were shorter with a two word window (see the upper panel of Flgure 2) than with a one word wIndow (see the lower panel of Flgure 2), $F(1,13)=25.93, \quad p<.001 . \quad F I x a t i o n$ durations were also affected by parafoveal mask manipulations, $F(2,26)=9.55$, $p<.001$, and there was a significant interaction of window size and parafoveal mask, $F(2,26)=4.35, p<.05$. Fixation durations were shorter when parafoveal letter information was presented than when It was not, In the One Word WIndow session, but not in the Two Word WIndow session. When word $n+1$ was present from the onset of fixation, IImIting the avaliablilty of parafoveal Information beyond that polnt had no systematic effect on fixation duration. With the two word wIndow the average fIxation duration was 232 ms and parafoveal manipulations had no rellable effect. The 
analysis of the Two Word Window session showed no effect of text, or delay ( $F s<1$ ), and no interaction $p>10$. This is consistent with the past findings on perceptual span of useful Information (Rayner, 1975). In most cases the two word window encompassed the perceptual span of useful letter information. Thus any manipulations outside the window had no effect on fixation duration.

An ANOVA of the One Word WIndow session ylelded a main effect of mask, $F(2,26)=9.72, p<.001$, and an interaction of text by delay, $F(4,52)=4.90, p<.01$. As seen in the lower panel of figure 2, fixation durations were shorter in the letter releasing conditions (Letters Released, Letters and Spaces Released) than in the condition in which only space information was released (Spaces Released). This suggests that avaliablilty of parafoveal letter information does facliltate processing of word $n+1$ when it is subsequentiy fixated. There was no effect of delaying parafoveal information.

In the One Word WIndow session, having had access to parafoveal letter information facliltated processing of the word when it was subsequentiy fixated. Fixation durations were shorter in letter preview conditions than in space only conditions. We wIII return to the issue of the beneflts of parafoveal letter information when we look at the word skipping and consecutive fixations data. 
Saccade length. Stat Istlcal analys Is of the saccade length data was as follows. All main effects and Interactions of the $2 \times 3 \times 3$ ANOVA were signiflcant beyond the .0001 level, as were the effects in the $3 \times 3$ ANOVA of the One Word WIndow session and the same analysis of the Two Word WIndow session.

In general, saccades were longer in the Two Word WIndow session than In the One Word WIndow session (see FIgure 3 ). Thls suggests that the spaces defining the beginning and end of word $n+1$ are Important In determInIng where to move. However, In order to evaluate the relative Importance of each of these boundarles a condition In whlch only the first space is released is needed (see Experiment 2).

The relationship between parafoveal letter and space Information was more complicated. If saccades were programmed solely on the basls of word boundarles, then a) there should have been no effect of delay in the Letters Released condltion, and $b$ ) saccades should have been longest In the Letters Released Condition at all delays (space Information was avaliable from the onset of fixation In this condition), and In the spaces Released condltion at a zero delay. The pattern of the data, however, is qulte different, as the mean saccade length in the Letters Released condition decreased with Increasing delay. Instead the best characterlzation of the One Word WIndow condition Is that the Letters and Spaces Released condition is the 
same as the Letters Released condition for the first $50 \mathrm{~ms}$ and then the same as the Spaces Released condition after that. Thus It appears that, the letter Information recelved late in the fixation was not providing any benefit beyond that of the space information that had been avallable since the onset of the fixation. This suggests that a reader may process some parafoveal letter Information early in a fixation, and use that Information when determining the next landing position. By $150 \mathrm{~ms}$ decislons are belng made on the basls of parafoveal space information alone. The pattern was similar In the Two Word WIndow condition (see Flgure 3 ); however, the effects were smalier.

It may be that ut IIIzIng low-level Information I Ike spaces is much faster than utilizing letters. Thus, there may not be enough time remaining in a flxation after the flrst $50 \mathrm{~ms}$ to utlilze the letter information to program the next saccade.

Word skipplng. Two characterlstics have dom Inated all of the data thus far. First, processing of parafoveal Information was possible far Into the flxation. Second, both letter and space Information from the parafovea were utilized early in a fixation. However, there is no evidence that letter Information was utIIIzed when delayed longer than $50 \mathrm{~ms}$.

Saccades may have been longer when letter and space 
Information was avallable early because readers sklpped over words more frequently when they had the letter Information avaliable in the parafovea and/or because they were less I Ikely to require two fixations on a word when they had parafoveal letter Information. Thus, It could be that readers were Just as efflclent at computing the landing position with space Information as with space and letter Information, but that letter Information In the parafovea allowed more efflclent processing of words in the text. That Is, the average saccade length may have been shorter in these conditions, not because readers were unable to compute the preferred vlewing location accurately, but because elther a second fixation was required in order to process the current word, or the succeedling word was skipped. In order to address thls the data were analyzed looklng at the number of $t$ Imes per sentence that the reader sklpped a word glven they landed on the word Immedlately prevlous and post, consecutively. The number of $t$ Imes the reader looked at the same word on two consecutive forward flxations was also analyzed.

First, let us conslder the word sklpplng data. Words were sklpped more frequently when there was a two word wIndow than when there was a one word wIndow. An ANOVA done with all the data excluding controls showed effects of wIndow size, $F(1,13)=4.95, \quad p<.05, \quad$ parafoveal mask, $F(2,26)=4.05, \quad p<.05$, and delay, $F(2,26)=19.16, p<.0001 ;$ and 
there was an Interaction of window slze and parafoveal mask, $F(2,26)=7.40, p<.01$.

When there was a two word window there was no systematic effect due to the type (letter or space) of Information beyond word $n+1$ that was made avallable to the reader. However, there was a decrease in the occurrence of word skippling as delay increased. In the analysis of the Two Word Window data, the only signiflcant effect was in the delay conditions, $F(2,26)=7.76, p<.01$.

The ANOVA done with One Word WIndow data ylelded effects of parafoveal mask, $F(2,26)=13.22, p<.001$, and delay, $F(2,26)=7.85, p<.01$. It appears that readers relled on word length, rather than letter information to determine when to skip a word. The lower panel of Flgure 4 shows that as space Information was delayed ( $S R$ and LSR), word skipping was reduced, whlle in the condition in which spaces were always avaliable from the onset of flxation and letter Information was delayed there was no apparent effect of delay.

it is not surprising to see that this pattern of results is simliar in character to that observed in the saccade length data. In conditions in whlch there was more word skippling, there were also longer saccades. LIkew Ise, In conditions in whlch there was less word skipplng shorter saccades were observed. This maps nlcely with the reading rate data as well. Past research has shown that readers tend 
to have Inflated fIxation durations Immediately preceeding a sklp (Hogaboam, 1983; Pollatsek, Rayner \& Balota, 1986). Therefore, one would expect longer flxation durations in conditions in which there was a greater occurrence of skipplng, all other things belng equal. However, the benefit In processing the currently fixated word due to having had parafoveal prevlew of lt may mask the effect in these data.

The data thus far have suggested that readers acquire some letter Information from parafoveal prevlew. Fixation durations were shorter and reading speed faster in conditions in which parafoveal letter information was released. Although the avallabllity of parafoveal letter Information did reduce the foveal processing time on the word when lt was subsequentiy fixated, the relative Infrequency of word skipplng Indlcates that parafoveal prevlew was not usualiy sufflclent for complete processing of a word. Most words stIII required a fixation.

Consecutive forward fixations. Readers tended to make two consecutlve flxations on the same word more frequently when there was a one word wlndow (see flgure 5). Thls makes sense slnce the mask began on the space that defines the end of word $n$ and therefore readers cannot easlly determine where the end of the current word Is. The $2 \times 3 \times 3$ Anova showed effects of wIndow slze, $F(1,13)=13.54, D<.01$; parafoveal 
mask, $F(2,26)=10.05, p<.001$; delay, $F(2,26)=20.14, p<.0001$; and Interactions of wIndow size and text, $F(2,26)=4.14$, $p<.05$; and window slze and delay, $F(2,26)=6.18, p<.01$. There were no signiflcant effects in the $3 \times 3$ ANOVA of the Two Word WIndow session.

The analysis done on the One Word WIndow session ylelded effects of parafoveal mask, $F(2,26)=10.62, \quad p<.001$, and delay, $F=(2,26)$, $p<.0001$. Letter Information was secondary to space information in determining when two consecutive fixations on the same word would occur: Letters Released and Letters and spaces Released conditions showed fewer consecutive fixations on the same word than the spaces Released condition. ThIs suggests that parafoveal letter Information reduces the processing load when the word is subsequently flxated. However, beyond $50 \mathrm{~ms}$ the Letters and Spaces Released condition Increases to more closely approximate the Spaces Released condition, suggesting that the delay of space information is critical.

If we take consecutive fixations on the same word as an additional reflection of the processing difficulty encountered in processing word $n$, then we see that this analysis fits well with what came before lt. There were more consecutive fixations on the same word when the end boundary of word $n$ was unavallable to the reader at the onset of the fixation. Other parafoveal space information played a role as well. As space Information was delayed the 
occurrence of consecutive fixations on the same word Increased. Their occurrence also Increased as parafoveal letter Information was delayed. This suggests that the shorter saccades seen in the spaces Released condition may be due In part to the Increased processing demands that arise when there is no prevlew of letter information rather than in an Inablity to accurately compute the preferred viewing location from space information alone. We would need to analyze the landing position within words in order Judge this (see Experlment 2). 


\section{EXPERIMENT 2}

The data from Experlment 1 suggested that word boundary Information plays a strong role in the programming of saccades. However, more evidence is needed in order to clarlfy some of the issues related to this conciusion. First, a better definition of the relation between parafoveal letter and space Information In the programming of saccades is needed. Second, how much of the Impact of word boundary Information is carrled by the space Immediately to the right of the currently flxated word? ThIrd, are these decislons under the direct control of the reader? FInally, there seem to be crltical changes in the relative Impact of the avallabllity of parafoveal letter versus space Information taking place durlng the first 50$150 \mathrm{~ms}$ of a fIxation and thus an Intermedlate delay would be helpful to determlne when these changes occur.

Experiment 1 demonstrated that most of the processing activity relevant to the questions belng addressed in this research primarliy utilizes information contalned within a two word window of text. Thus, the present experlment I ImIted the InItIal presentation to a one word wIndow of text In all conditions. When the mask was IIfted in this experiment, Information was IImIted to a two word wIndow, rather than releasing the entlre IIne, as was done 
previousiy.

The following example lilustrates a two fixation sequence in the Letters and spaces Released condition.

The cat drank $x \times x \times x \times x \times x \times x \times x \times x \times x \times x \times x \times x \times$ (onset of f (xation)

The cat drank from $x \times x \times x \times x \times x \times x \times x \times x \times x \times$ (100 ms later)

The cat drank from $\times x \times x \times x \times x \times x \times x \times x \times x \times x \times$ (new flxation)

The experiment was divided Into two sessions. In one session, all masking began on the space Immedlately after the foveal word, and in the other session, all masking began on the first letter of word $n+1$. These wll l be referred to as the Flrst Space FIIled and FIrst space Open sesslons, respectively. The First space filled manipulation is sImIlar to the One Word WIndow manlpulation of Experlment 1 , except for the fact that only information about word $n+1$ is released, rather than the entire I Ine of text. The previous example I I Iustrates the FIrst space FIIled manipulation. In the FIrst space Open session the parafoveal mask would begin on the first letter of word $n+1$ rather than on the space preceding it.

It can be argued that fllling the space to the right of the currently flxated word Interferes with foveal word Identification by obscurling the end of the foveal word, whlle at the same time Interefering with parafoveal word boundary Information by masking the space prevlous to word $n+1$ (Pollatsek \& Rayner, 1982). Leaving thIs crltical space 
open clearly has the opposite effect. It removes potentlal Interference in Identification of the currently fixated word. But it also provides parafoveal word boundary Information that may be critical to determining where to move the eyes next. By using a symbol that is distinctiy different from the letters of our alphabet (1.e., the grating) It may be possible to effectively mask the space while still signaliling the end of the currently fixated word. If thls is successful there should be greater Interference in the saccade length data in the first space Fliled session than in the First space Open session, but not in the fixation duration data.

The parafoveal mask conditions are consistent with those employed in Exper Iment 1; SR, LR, LSR. However there Is one exception. The Letters Released condition would be redundant across the two sessions, since it is the presence or absence of the first space at onset of fixation that differentlates the two sessions, and that space information is avaliable from the onset of fixation at all delays in this condition. Therefore, the Letters Released condition was omltted from the first space fll led session and a new condition, In whlch only the first space is released after the varlous delays, was added to replace It. An example fol lows.

Thex $x \times x \times x \times x \times x \times x \times x \times x \times x \times x \times x \times x \times x \times x \times x \times x \times x$ (onset of f(xation) 


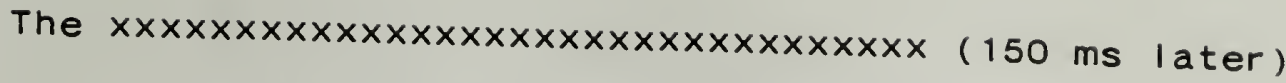

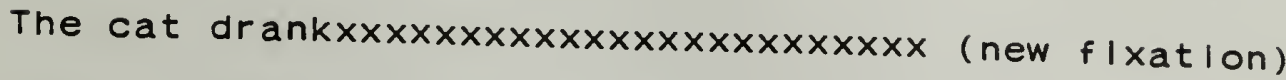

This condition will be referred to as the First space Released condition (FSR). It was assumed that this condition should provide some insight into the relative Importance of the flrst and second parafoveal space in saccadlc programming.

Before addressing the relationshlp between parafoveal letter and space Information, let us review some Important polnts from Experlment 1. The evidence from Experiment 1 demonstrated that the parafoveal space Information strongly Influenced where a reader moved $h l s$ or her eyes during reading. There were hints that parafoveal letter Information may Influence where to move as well. Saccades were longer In the Letters Released condition than In the spaces Released condition at short delays. At longer delays, the Letters Released condition was not different from the spaces Released condition at a 0 delay. Both of these conditions released space Information from the onset of a flxation. There are two possible Interpretations of this result that remaln und fferentlated by Experlment 1 .

According to the first Interpretation, both types of parafoveal Information (letters and spaces) are used to compute landing posltion under normal clrcumstances, but space Information is processed more rapldiy than letter Information. Thus, at long delays there would not be enough 
time for letter Informaton to be utlilzed. In both the Letters Released and Spaces Released conditions the reader would compute a saccade based on space information alone and there would be no difference between the two conditions. However, at short delays, when parafoveal letters are avaliable early in the fixation, Input from the two types of Information would combine. Thus, readers would be more I Ikely to saccade further into the next word or skip over It, and less likely to fixate the same word twice. Hence, there would be a benefit in the Letters Released condition at short delays.

According to the second interpretation, saccades are programmed solely on the basis of parafoveal space information. However, the decision of when to move and whether to reflxate word $n$, move to word $n+1$, or sklp to word $n+2$ is decided on the basis of letter information. Thus, processing difflculty on the currently fixated word may dictate making a second fixation on the same word. Conversely, highiy predictive context comblned with parafoveal preview of letters may make fixation on word $n+1$ unnecessary (Balota, Pollatsek, \& Rayner, 1985). Thus, the reader may sklp over the word. As was the case under the first interpretation, space information is processed more rapldiy than letter information, so that there would not be sufficient processing time for letter information to be utlilzed at long delays. Therefore, saccades would be 
programmed without beneflt of parafoveal letter prevlew in both the Letters and Spaces Released condition and In the Spaces Released condition. Hence, there would be no difference between the two conditions. In contrast, when letter and space Information are avallable early, parafoveal letter preview would effectively reduce the processing difficulty when the word is subsequently fixated. Two consecutlve flxatlons on the same word are less IIkely and word skippling is more IIkely to occur. Thus, there would be a benefit in the saccade length data In the Letters Released condition. Under this interpretation, once the decision was made as to whlch word to flxate, the landing position would be computed on the basis of the length of the word. In the absence of parafoveal letter information the reader would baslcally be maklng a binary decision with regard to which word to flxate: elther a second fixation is required to process the foveal word, or the decision is move to the next word. It is highly unlikely that a reader would choose to skip a word that they have never seen. Once the word cholce Is made, space Information is consulted to compute the approprlate landing position in that word, based on lts length. It is interesting to note that this second model suggests that the same process is used to compute landing position in the case of consecutive fixations on the same word and would therefore predict that reflxation landing position would vary systematically with word length in much 
the same way that the InItlal preferred viewing location does.

Both interpretations fit the data thus far. However they make different predictions about where in a word the reader will InItlaliy land. The first Interpretation predicts that initial landing position should be further to the right In the Letters Released condition, due to the combinatorlal power of the two sources of relevant Information. Thus the differences between the Letters Released and the spaces Released conditions would be apparent in the consecutive fixations, word skipping and landing position data. The second interpretation suggests that the differences between the two conditions in the saccade length data are primarliy due to differences in word skippling and consecutive fixations on the same word. In the Spaces Released condition, when there is no letter Information in the parafovea, there would be more consecutive fixations on the same word and less word skippling than there would be in the conditions which provide preview of letter information. Since landing position within the word is calculated solely on the basis of word boundary information under this interpretation the prediction would be that there would be no difference in the Inltial landing position on word $n+1$ between the two conditions, given that the reader was making the saccade from the Immedlately previous word. 
In the model presented in the Introduction to this paper there was an assumption that attention moves serlally, word by word, across the text. ThIs assumption makes a great deal of Intultive sense since word order is critlcal to comprehension of wrltten text (at least In English). Take the following palr of sentences as an example:

The baby blt the dog.

The dog blt the baby.

The words contalned in the two sentence frames are Identlcal. However, by changlng the word order we are able to descrlbe two somewhat different events. If attention travelled sequentialiy word by word across the text that would certalnly help to Index the order of the words in the sentence. However, up to now there has been l tttle evldence provlded to test this assumption. In the Letters Released condition of this experiment the onset of word $n+1$ is delayed at varlous Intervals relative to flxating word $n$. If this model is correct then there should be no difference between having word $n+1$ avallable at the onset of a flxation and the case in whlch it is delayed avery short perlod of time, since it would not be attended to untll word $n$ was processed. ThIs prediction was tested by looklng at comparisons between fIxation duration In the Letters Released condition at a 0 and a $50 \mathrm{~ms}$ delay.

Experlment 1 demonstrated that when parafoveal space Information was delayed $250 \mathrm{~ms}$ there was stIII some beneflt over not having the space Information at all. This result 
Is Important for two reasons. 1) it demonstrates that readers may continue to attend to information in the parafoveal region throughout the duration of a fixation. 2) It suggests that readers are able to process space Information more raplaly than letter Information. In the data from Exper Iment 1 there appeared to be crltical changes In the way letter and space Information was utIIIzed that took place between 50 and $150 \mathrm{~ms}$. In the present exper Iment the $250 \mathrm{~ms}$ delay was el ImInated and a $100 \mathrm{~ms}$ delay was added. The delay conditions for the present experiment were $0,50,100,150$, and an InfInIte delay.

In order to test the direct control hypothesis more stringently, the physlcal extent of the parafoveal Information recelved must be more tightly constralned than It was in Exper Iment 1 and an analys Is is needed whlch is dependent upon some factor whlch varles falriy unpredictably from fixation to flxation. We have controlled the physlcal extent of the Information avaliable by IImIting the release of parafoveal Information to a two word window In all conditions of the present experiment.

In addition to the analyses that were done on the data from Experiment 1, a landing position analysis dependent upon word length was done in order to address the Issue of direct control. Since word length varles falriy unpredlctably from one word to the next the InItlal landing position within a word should vary with word length If eye 
movement guldance decislons are under direct control. This analysis will also serve to distingulsh the two Interpretations of the relation between letter and space Information in the programming of saccades that were out I Ined earller.

\section{Method}

Subjects. The subjects were 14 pald volunteers from the UnIversity of Massachusetts and were simllar to the subjects In Experiment 1. Nine of them were subjects in Exper Iment 1 .

Stimuli. The stimulus materlals for this experiment were similar to those used In Experiment 1. Twenty-elght new passages were created for the present experiment according to the criterla outilned In Experiment 1 (see Append $(x \quad C)$.

Apparatus and Procedure. The equipment and procedure were the same as those described in Experiment 1.

Experimental Design. The design of the present experiment was a modification of that used in the previous experiment. The FIrst space Open and FIrst Space Filled sesslons replaced the One and Two Word WIndow sessions of 
Experlment 1 , and the parafoveal mask by delay comblnations differed across the two sesslons. In the first space fllled session, the three parafoveal mask (Words and spaces Released, Spaces Released, FIrst Space Released) by flve delay conditions $(0,50,100,150,1 n f|n| t e)$, ylelded a total of 15 posslble comblnations. However, all parafoveal mask conditions ylelded the same display at an infinite delay. These three cells were reduced to one, and a single cell of normal reading was added for comparlson purposes. There were a total of 14 condltions within the session. Each condition was presented for one elght sentence block.

In the First space Open session the three parafoveal mask conditions were simliar to those used In Exper Iment 1 , In that elther spaces were released (SR), spaces were present at the onset of a flxation and letters were released (LR), or letters and spaces were released sImultaneously (LSR). However, the parafoveal mask began on the first letter of word $n+1$, and the extent of the parafoveal Information exposed never exceeded a two word window. These were crossed with five delay conditions to yleld 15 possible combinations. In this session the Letters and Spaces Released condition, and the Letters Released condition resulted In Identical conditions at a o delay interval. These were reduced to one cell in the deslgn. The Letters Released condition at an Infinite delay and the spaces Released condition at a o delay both operationallzed as a 
condition in which only parafoveal space information was avaliabie from the onset of each new fixation. These two celis were also reduced to a single cell, and a cell of normal reading was added as a control. Each session consisted of one space condition, with the order of three parafoveal mask by five delay conditions (minus one) partialiy counterbalanced across the 14 subjects.

\section{Results and Discussion}

For each subject reading performance was assessed by the same measures as used in Experiment 1: reading rate, fixation duration, saccade length, word skipplng and consecutive fixations on the same word. Two additional measures were included. First, the mean landing position (measured in letter position) on words of a given length was calculated (Landing Position). Second, the proportion of times a word of a given length was fixated was calculated (Landing Frequency). These analyses Included only left to right movements on consecutive words within the passages, and only looked at first fixations on a word. The space Immediately preceeding word $n$ was considered the first position.

In the present experiment a 3 parafoveal mask $(S R, L R, L S R) \times 3$ delay $(50,100,150)$ ANOVA was done on the data from each measure for the FIrst Space Open session. A 
separate 3 parafoveal mask (FSR,SR,LSR) $x 3$ delay $(50,100,150)$ ANOVA was done on the data from the first space FIlled session. These analyses did not Include the control conditions, although the control conditions are Included In the flgures as a frame of reference. Relevant comparisons are clted In thelr respective sections of this paper.

Reading rate. There was an effect of parafoveal mask, $F(2,26)=9.44, \quad p<.01$, In the FIrst space Open session of Experlment 2. It Is apparent from the left panel of Flgure 6 that reading rate was faster In the letter prevlew conditlons (LSR,LR) than It was when there was no letter prevlew (SR). There was also an effect of delay, $F(2,26)=7.09, p<.01$ and a marglnally slgnlflcant Interaction of parafoveal mask by delay, $F(4,52)=2.36, p<.06$. Reading rate decreased as delay Increased In the letter releasing conditions, whlle the space releasing condition remalned unaffected by the delay.

The Flrst Space Fll led session contalned two space releasing conditions (FSR and $S R$ ), and one condition In whlch both letters and spaces were released (LSR). Agaln, there was an effect of parafoveal mask, $F(2,26)=12.97$, $p<.01$; and the lower panel of Flgure 6 IIIustrates clearly that In the parafoveal letter preview condition (LSR) reading rate was faster than it was in the condltions whlch released only parafoveal space Information (SR, FSR). 
Reading rate decreased as delay Increased In all conditions. The effect of delay, $F(2,26)=24.89$, $p<.01$, substantlates the fact that reading rate decreased as delay increased In all conditions.

Parafoveal prevlew of letter Information had a positive Influence on reading rate. That is, reading rates were faster In the letter preview conditions than in conditions In whlch no parafoveal letter prevlew was avallable. However, these data do not Indlcate whether or not any of this effect was due to the use of parafoveal letter Information in the programming of saccades. The fact that delay of letter Information slowed the reading $t$ Ime does Indicate that letter Information was utilized in some capacity as late as $150 \mathrm{~ms}$ Into a flxation. Thls suggests that readers were stlll attending to some aspect of the parafoveal text far Into the flxation. For a more detalled Interpretation we wIII have to look to other measures.

Flxation duration. The fixation duration data was simliar In character to the reading rate data. The $3 \times 3$ ANOVA done on the FIrst Space Open data showed effects of parafoveal mask, $F(2,26)=9.88, p<.01$ and delay, $F(2,26)=2.56, p<.10$. As seen In the upper panel of Flgure 7 , it is the presence or absence of letter Information that differentlates the parafoveal mask conditions. The two letter releasing condltions (LSR, LR) were almost Identlcal, whlle flxatlons 
were longer in the condition which released only spaces.

A $3 \times 3$ ANOVA of the data from the first space filled session Indicated an effect of parafoveal mask, $F(2,26)=3.92$, $p<.05$, and no effect of delay. The rlght panel of Flgure 7 shows that fixatlons were shorter In the Letters and spaces Released condition than in the Spaces Released condition. This makes sense, since the Letters and Spaces Released condition provides parafoveal preview of letter Information, and the spaces Released condition does not. However, the first space Released condition showed slightiy shorter average flxations than the Spaces Released condition as well. That is, there were shorter fixation durations when only the first space was released than when the first two parafoveal spaces were released. If we look ahead to the word skipplng and consecutlve fixatlons data, there were more consecutive fixations on the same word and fewer skips in the first space Released condition than in the other two conditions (see Figs. $9 \& 10$ ). Flxation durations tend to be longer preceeding a skip (Hogaboam, 1983; Pollatsek, et al, 1986). Conversely, fixation durations tend to be shorter when processing is distributed across two consecutive flxations on a single word (O'Regan \& Levy-Schoen, 1987). These two factors deflated the mean fixation duration in the first space Released condition. Thus, although only one parafoveal space was avallable in the First Space Released condition the average fixation 
duration was shorter than in the case in which two parafoveal spaces were released.

The Letters Released condition (o delay) ylelded shorter fixations than the same condition with a 50 ms delay; $t(1,13)=3.81, p<.002$. The model out IIned earlier predicted no difference between these conditions based on the assumption that attention is shifting word by word. This will be discussed further in the general disccussion.

Saccade length. The First space Open data (see the upper panel of Figure 8) showed the same crossover pattern that was so prevalent in Experiment 1, suggesting that saccadic programming relied heavily on the release of space information. That is, the Letters and spaces Released condition was more like the Letters Released condition up to a $50 \mathrm{~ms}$ delay and after $50 \mathrm{~ms}$ it began to decline unt II it matched the Spaces Released condition. An ANOVA done on the First Space Open data Indlcated effects of parafoveal mask, $F(2,26)=4.28, \quad p<.05$ and delay, $F(2,26)=11.68, \quad p<.01$. Although the Interactive pattern was there, the interaction of parafoveal mask by delay was not slgniflcant due to the fact that all effects were so small in the case when the flrst parafoveal space was open from the onset of the fixation.

The $3 \times 3$ ANOVA of FIrst space Fll led data ylelded effects of delay, $F(2,26)=4.55, \quad p<.05$, and parafoveal mask, 
$F(2,26)=12.97, \quad P<.01$, and a signiflcant interaction of parafoveal mask by delay, $F(4,52)=3.48, p<.05$. The lower panel of Figure 8 lllustrates clearly that saccades were longest when there was a parafoveal preview of letter and space Information (LSR). They were shortest and showed Ilttle Influence of delay when only the first space to the right of the currently fixated word was released (FSR).

In the first space filled condition the Letter and Spaces Released condition malntalned a consistent benefit over the Spaces Released condition (see the lower panel of Figure 8). Was this because the first saccade into a new word was more conservative wlthout letter Information; or because without beneflt of parafoveal prevlew of letters, processing the foveal word requlred more work (1.e., more cases of two consecutive flxations on the same word, which would tend to requlre very short saccades)? To answer this we need to look at the consecutive flxation data and at the landing position analysis. The consecutive flxation data did Indicate that there were more consecutlve fixations on the same word In the SR condition than In the LSR condition (see the lower panel of Figure 10). Thls suggests that readers were having greater processing difflculty when they flxated a word If there was no parafoveal prevlew of letters.

Readers were InItlally landing in the same position in a word whether they had parafoveal prevlew of letters and 
spaces, or only spaces (see landing position analysis). This suggests that the saccade lengths were shorter in the spaces Released condition than in the Letters and Spaces Released condition because readers were more likely to need to fixate a word twlce in order to process it if they had not had parafoveal prevlew of the letters and not because they were less capable of computing the preferred viewing location. Indeed the data Indicate that readers were quite good at computing the preferred vlewing location based on word boundary information alone (see landing position analysis). However, they did have greater difflculty processing a foveal word when they had not had parafoveal prevlew of Its letters (Ionger average fixation durations; more consecutive f (xations).

Word sklpplng. Fewer words were sklpped as the parafoveal Information was delayed in the first space Open session, $F(2,26)=2.68$, $p<.09$. There was no effect of parafoveal mask (see the upper panel of Flgure 9). In this session all the parafoveal mask conditions released the first two parafoveal spaces. Both spaces must be present in order to compute word length. As suggested in Experlment 1, word length and syntax may strongly cue the location of function words. In that case the decision to skip a word could be made in the absence of letter Information.

In the first Space FIIled data the ANOVA Indicated an 
effect of parafoveal mask, $F(2,26)=4.84, p<.05$. The First Space Released condition had fewer skips than the conditions which released the first and second parafoveal space (SR \& LSR), as you can see in the lower panel of figure 9 . There was also an effect of delay, $F(2,26)=6.05, p<.01$, and there were fewer skips in all conditions as parafoveal information was delayed.

Consecutive forward fixations. A $3 \times 3$ ANOVA done on the data from the First space Fllled session Indlcated that there was an effect of parafoveal mask, $F(2.26)=6.88, p<.01$. Look Ing at Figure 10, It can be seen that there were more consecutive fixations in the spaces Released condition than In the Letters and Spaces Released condition. ThIs suggests that readers experlenced more difflculty processing foveal words when they had not had parafoveal prevlew of letter information. The greatest number of consecutive fixations on the same word occurred when only the first space to the right of fixation was released (FSR). In this condition there was no parafoveal preview of letter information and It was Impossible to determine the length of a word before it was flxated. Readers did not have the information necessary to compute the optimal InItial landing position for processing the word; nor did they have prevlew of Its letters to facllitate processing when they did land on It. It was also the case that the longer the delay of parafoveal 
Information the greater the occurrence of consecutive fIxations on the same word, $F(2,26)=21.26, \quad 0<.01$. The occurrence of consecutive flxations on the same word rose sharply as delay Increased in the two conditions in which the first two parafoveal spaces were released (LSR,SR). However In the FIrst Space Released condition there were a large number of consecutive fixations on the same word at all delays. ThIs Interaction of parafoveal mask by delay was signIflcant, $F(4,52)=2.87, p<.05$.

A $3 \times 3$ ANOVA of the FIrst space Open data Indlcated that the maln effect of parafoveal mask was signlficant, $F(2,26)=10.59, \quad p<.01$. That Is, consecutlve flxations on the same word occurred most frequentiy in the Spaces Released condition (where there was no parafoveal prevlew of letter Information) and there were fewest consecutive fixations on the same word In the Letters and spaces Released condition (see the upper panel of Flgure 10). All conditions were affected by the delay Interval, $F(2,26)=11.62, p<.01$. However, the delay effect was mInImal In the spaces Released condition; there was a marginal Interaction, $F(4,52)=2.21$, $\mathrm{p}<.09$

The data presented thus far suggest that saccades were computed based on word length Information, provided that there was no foveal processing difflculty. When there were problems with the foveal word, whether due to a lack of parafoveal prevlew of letter Information, or an InabIIIty to 
determine Its end, refixations were more IIkely to occur. Otherwise, saccades were computed based on parafoveal word length information.

Landing position analyses. ThIs was an analysis of the mean landing position (measured in letter position) on words of a glven length. A separate 3 (parafoveal mask) $\times 3$ (delay) $\times 6$ (word length) ANOVA was done on the data from each session. In the First space Open session all maln effects were sIgnIflcant, $p<.001$ (see Table 1a). In the FIrst Space FIlled data all maln effects were slgnlflcant, $p<.0001$, and there was an Interaction of parafoveal mask by word length, $F(10,130)=2.18, p<.05$ (see Table 1b). Parafoveal word length had very I Ittle Influence on the FIrst Space Released condition. The Spaces Released and the Letters and Spaces Released conditions showed a InIt|al posltions that shlfted further to the rlght as word length Increased. The mean landing positions in the spaces Released and In the Letters and Spaces Released conditions differed by only two tenths of a character position condition (SR, $x=2.5 ; \quad$ LSR, $x=2.7$ ). Thls difference was not rellable, $F(1,13)=2.07, p<.17$, nor was the Interaction, $F(5,65)=1.51, p<.20$. 
Table 1a

Landing Position with FIrst space Open In Exper Iment 2

\section{Word Length in Number of Letters}

3

4

5

6

7

Text

more

$\begin{array}{lllllll}\text { SR } & 1.7 & 2.1 & 2.6 & 3.2 & 3.1 & 3.4 \\ \text { LR } & 2.0 & 2.5 & 2.8 & 3.3 & 3.7 & 4.1 \\ \text { LSR } & 1.8 & 2.3 & 2.9 & 3.5 & 3.5 & 3.9\end{array}$

Table $1 b$

Landing Position with FIrst space Fll led In Experiment 2

Word Length in Number of Letters

$\begin{array}{lllllll} & 3 & 4 & 5 & 6 & 7 & 8 \text { or } \\ \text { mext } & & & & & & \text { more }\end{array}$

Text

$\begin{array}{lllllll}\text { SR } & 1.6 & 2.2 & 2.3 & 2.9 & 3.0 & 3.1 \\ \text { LSR } & 1.6 & 2.3 & 2.6 & 2.9 & 2.9 & 3.7 \\ \text { FSR } & 1.6 & 1.9 & 2.1 & 2.3 & 2.5 & 2.6\end{array}$

All of thls lends support to the story told earlier. The data from the First space FIIled session Indlcated that InItIal landing position on a word was not different glven 
parafoveal space Information alone, or letter and space Information, as long as the space information was delayed equaliy in the two conditions. In the case in which only the first parafoveal space was released the initial landing position was more conservative. In the first space open data the initial landing position was further into the word in the condition in which space information was avaliable from the onset of a fixation (LR). The other two conditions delay the release of parafoveal space information, and therefore had more conservative landing positions, especlally at longer delays.

Landing frequency analyses. This was an analysls of the proportion of $t$ Imes a word of a given length was fixated. The $3 \times 3 \times 6$ ANOVA of the first space Fliled data showed that there was a maln effect of parafoveal mask, $F(2,26)=5.52$, $p<.01$, and a maln effect of word length, $F(2,26)=41.12$, p<.001. There was no signiflcant effect of delay. Words were landed on more frequently when there had been no parafoveal prevlew of letter Information than when the letters had been prevlewed. Word length was the only signiflcant factor in the First space Open session, $F(5,65)=41.39, p<.0001$ (see Table $2 a \& b)$. 
Table $2 a$

Landing Frequency with FIrst space Open In Exper Iment 2

Word Length In Number of Letters

3

4

5

6

7

8 or

Text

more

$\begin{array}{lllllll}\text { SR } & 37 & 48 & 60 & 62 & 58 & 67 \\ \text { LR } & 33 & 46 & 55 & 66 & 62 & 66 \\ \text { LSR } & 36 & 44 & 60 & 59 & 60 & 61\end{array}$

Table $2 b$

Landing Frequency with Flrst space Fll led

In Exper Iment 2

Word Length in Number of Letters

$\begin{array}{llllll}3 & 4 & 5 & 6 & 7 & 8 \text { or }\end{array}$

more

Text

$\begin{array}{lllllll}S R & 40 & 59 & 62 & 62 & 65 & 67\end{array}$

$\begin{array}{lllllll}\text { LSR } & 34 & 51 & 57 & 61 & 68 & 70\end{array}$

$\begin{array}{lllllll}\text { FSR } & 48 & 58 & 65 & 69 & 72 & 73\end{array}$




\section{GENERAL DISCUSSION}

The major results of the present study are as follows. First, most of the Information used to determine where and when to move the eye is contalned wIthIn a two word wIndow to the right of flxation: effects were negliglble In the Two Word WIndow condition of Experlment 1 . In this condition no parafoveal information was altered within a two word window to the right of the polnt of fixation. Second, masking the f Irst parafoveal space to the rlght of the currently fixated word with the square wave grating caused IIttle If any Interference In the processing of the foveal word. ThIrd, the presence of parafoveal letter Information had a facll Itative effect on the reading rate, flxation duration, consecutive flxation data, and saccade length (at short delays). But parafoveal letter Information had very I It le effect on the reader's InItlal landing position within a word. Fourth, prevlew of the flrst two spaces to the right of the current fixation resulted In longer saccades and InItlal landing positions that more closely approximate the preferred vlewing location, than prevlew of only the first space. FIfth, there was also a beneflt of having space Information present even when this Information was delayed $250 \mathrm{~ms}$. These findings provide Information relevant to 
three major concerns in reading research: direct control of eye movements, the role of word boundary and parafoveal letter information in reading, and the role of attention.

\section{Direct Control of Two Independent Processes}

In the present experiments, delay of parafoveal letter or space Information had differentlal effects on when and where a reader moved hls or her eyes and these declsions were based on Information recelved within the current fixation. The first clear demonstration that events on a fixation can affect the length of the next saccade and/or the duration of the current fixation was provided by Rayner and Pollatsek (1981). They varled physlcal aspects of the text randomiy from fixation to fixation and showed that the behavior of the eyes mirrored what was seen on that fixation (see also Morrison, 1984). In addition, Rayner \& Pollatsek (1981) showed that the processes controliling saccade length and fixation duration were independent, so that there is reason to belleve that the decislons of where to move the eyes and when to move the eyes can be made independentiy (Rayner \& McConkle, 1976).

The present study replicates the finding that eye movement guldance is under the direct control of the reader. That is, decisions can be made based on information recelved In the current fixation. Both the Landing Position and the 
Landing Frequency analyses were conditional upon word length. Word length varled falriy unpredlctably from one word to the next in the text, and therefore from fixat ion to flxation. Both the landing frequency, and the landing position analyses, Indicated that there were systematic differences in the reading pattern due to space, letter, and delay manlpulations, given word length. Since readers could not successfully predlct word length In advance, and parafoveal prevlew was IImIted to word $n+1$, these results support a direct control model of reading (Rayner \& Pollatsek, 1981) In which the amplitude of a saccade is computed on the basis of parafoveal information obtalned on the current flxation.

Both experiments provide additional evidence to support the claim that decisions of when and where to move are controlled by Independent processes. Flxation durations were longer when parafoveal letter Information was delayed or absent, while delay or elimination of word boundary Information beyond the space that defines the end of the currently fixated word had no effect on subsequent fixation durations. When to move was Influenced by the processing time on the currently flxated word. When the reader had no parafoveal prevlew of letter information, or when the space definlng the end of the word was fll led, processing was more difflcult and therefore took more $t$ Ime.

Where to move was most affected by the avallabllity of 
parafoveal space Information. The landing position data Indicated that, In conditions In whIch parafoveal letter Information was avaliable, the landing position within a word of a glven length was not different from the conditions In which only parafoveal space Information was avallable to the reader, except in the case of very long words.

To summarlze, declsions about where and when to move the eyes during reading are controlled by Independent processes that utllize somewhat different aspects of the parafoveal Information. When to move is dictated by the processing demands of the currently fixated word. Parafoveal preview of letter Information alleviates some of the processing difflculty on a word when it is subsequentiy fIxated. This results in shorter fixation durations when the reader has had parafoveal prevlew of letter information. Parafoveal letter Information may also Influence whIch word wIII be flxated on the next landing, but it is word length that has the stronger Influence on the InIt|al landing position within a word. The first parafoveal space to the right of the currently fixated word is utlilzed by both processes, and where to move is determined primarliy by the length of the word to be fixated.

\section{Role of Word Boundary Information}

It has been suggested that saccades are programmed 
solely on the basls of word length information. There were several important patterns present in the data that relate to the role of word boundary information in the programming of saccades. There is an interesting crossover pattern in the One Word Window session of Experiment 1 which is replicated in the FIrst space Open session of Experiment 2 . At short delays there is a clear benefit for conditions whlch release letter information (LR, LSR), over conditions which release only space information (SR). However, as the delay of parafoveal information increases, the emphasis shifts, and It is the release of space information which seems to be the crltical component. That is, as the delay extends beyond the first $50 \mathrm{~ms}$ of the fixation, the Letters and Spaces Released condition begins to look I Ike the spaces Released condition. The characteristlc that these two conditions have in common is the timing of the avallablilty of space Information. Also, as the delay extends beyond 50 ms, the Letters Released condltion ylelds saccades that are similar in length to those of the spaces Released condition at a o delay. Here, the commonality between the two conditions is that in both cases space information is avaliable from the onset of a fixation. When we turn to the consecutive fixation and landing position data we find that the benefit observed in the letter releasing conditions at short delays is not due to differences in landing position within words. That is, readers are not more accurate in 
targeting the preferred viewing location within a word with the letter Information avaliable. However, there were fewer occurrences of two consecutive fixations on the same word when parafoveal letter Information was avallable within the first $50 \mathrm{~ms}$ of the fixation. So lt appears that the advantage observed in the letter releasing conditions at a short delay is not due to the Influence of letter Information on landing position, but rather, a reflection of the facllitation of foveal processing due to avallabllity of parafoveal letter Information.

In the First space fllied condition of Experiment 2 the Letters and Spaces Released condition did show a conslstent benefit over the spaces Released condition at all delays. However, there were more consecutive flxat Ions on the same word in the spaces Released condition than in the Letters and Spaces Released condition, Indlcating that readers were having greater processing difflculty on the currently fixated word when they had not had parafoveal letter Information avaliable. ThIs necessitated making a second fixation on that word in order to process it. The saccades withln words tended to be shorter than saccades to a new word, thus bringling the average saccade length down. Readers were Inltially landing in the same position on a new word whether they had parafoveal prevlew of letter and space Information, or only spaces. Word sklpplng and the frequency with whlch readers landed on words of a glven length were 
also not influenced by prevlew of letter Information. These data suggest that readers were quite good at computing the preferred viewling location on the basls of space information alone.

We know from prevlous research (Pollatsek \& Rayner, 1982) that a lack of parafoveal space Information results in shortened saccades, even when all of the parafoveal letter information is present. In the current data the saccades were shortest, and the InItIal landing position was most conservative, across delay conditions, when only the first parafoveal space was present. WIthout the space that defines the end of word $n+1$, the saccades were consistently shorter than when both the beginning and ending spaces for that word were present. There were also more consecutive flxations and fewer skips in this condition. Clearly both spaces are necessary to accurately program a saccade to the preferred vlewlng location.

To summarlze, It appears that saccades were shorter when only parafoveal space Information was avallable because readers had more difflculty processing a foveal word when they did not have parafoveal prevlew of lts letters (longer fixation durations, more consecutive fixations). Without beneflt of letter prevlew the foveal processing load was greater: more words requlred two flxatlons in order to be processed. Whlle letter Information may Influence whlch word a reader will flxate, space Information is used compute 
the landing position within the word.

Numerous studies have shown that readers utllize partial letter information from parafoveal vision in reading (Balota et al., 1985; Inhoff \& Rayner, 1987; LIma,1987; McConkle \& Rayner, 1975; Rayner et al.,1981; Rayner, Well, Pollatsek, \& Bertera, 1982). The data reported in the present experiments indlcate that in those conditions in Which parafoveal letter Information was presented flxation durations were shorter, reading speed was faster, and the number of times a reader refixated the same word on two consecutive fixations was reduced, compared to conditions in which no parafoveal letter information was presented. these results help to lliustrate the fact that readers are using letter Information acquired parafoveally to facllitate processing of word $n+1$ when it is subsequently fixated.

The majorlty of words in a text are flxated by the reader. However, it is the case that some words are sklpped, suggesting that foveal processing of every word is not necessary. Rayner and McConkle (1976) showed that word length Influences the probability that a word wIII be sklpped. Just and Carpenter (1983) reported that when subjects read technical materlal they sklpped $62 \%$ of the function words. Balota et al (1985; see also, Ehrlich \& Rayner, 1981) showed that readers were less I Ikely to flxate the same word twice in succession, and more likely to skip a word, when lt was highly predictable in the sentence 
context. Visualiy similar nonwords were as likely to be skipped in the highly predictable condition as were the actual words, suggesting that readers were sklpplng words on the basls of partial letter information. It was not the case that readers were fully processing the parafoveal word before declding to sklp It, slnce they sklpped visualiy similar nonwords as well as the actual word that was predicted by the context. Balota et al. argued that visual and contextual Information have separate Influences on parafoveal processing and that it is the convergence of the two types of Information on a particular lexical representation that ylelds this effect.

The data presented here showed that word sklpping was Influenced by word length. But there was surprisingly Ilttle benefit of letter prevlew, beyond a o delay. This Information taken with what we know from prevlous research suggest that declsions of where to move are declded primarliy on the basls of word length Information in the parafovea, whlle letter Information has a strong Influence on the ease or difflculty of processing the word when it is fIxated. The parafoveal letter Information may Influence decislons about whether one fixation, two flxations, or no flxations on the upcomlng word are necessary. The conditions In whlch space Information was avallable from the onset of a fixation and letter Information was delayed ylelded far greater beneflt than when both types of 
parafoveal Information were released simultaneously. Letters and spaces released simultaneousiy showed some beneflt over spaces released alone when the delay was very short. ThIs suggests that both aspects of the parafoveal information are attended to simultaneousiy but that letters are not processed as qulckly as spaces. It may be that space Information is registered by low-level perceptual processes which are falriy automatic and therefore require little or no cognitive effort. However, when letter information arrives late there is not enough time to process and utlilze It before the current fixation ends. Once the reader has declded which word to land on, the landing position is computed based on the word length information with little regard for the letter content of the word. since space Information is acquired so much more rapldiy than letter information there is little benefit to releasing the spaces In advance of the letters. Partlal word Information Is used to determine whlch word a reader wIII fIxate and It Is word length Information that is used to determine where in the word the reader wIII land. An Intriguing extension of the present research would be to explore whether or not syntactic information comblnes with highly famillar letter Information to explain the skipping of function words since the word length factor is confounded with the fact that function words tend to be short. 


\section{The Role of Attention In Eye Guldance}

The model presented in the Introduction to this paper contalns the assumption that attention moves word by word across the text in a serlal fashion. Prevlous research has shown that masking the foveal word after $50 \mathrm{~ms}$ has little or no effect on readling (Rayner et. al.,1981). Thls suggests that by $50 \mathrm{~ms}$ attention has shlfted away from the foveal word. No difference between the Letters Released condition at a 0 delay and at a $50 \mathrm{~ms}$ delay would be strong evidence that attention shlfted from the foveal to the parafoveal word at approximately $50 \mathrm{~ms}$. However, since releasing letter Information at the onset of a flxation ylelded some benefit over delaying that information $50 \mathrm{~ms}$ it is not clear when this shift of attention occurs. It is possible that some low-level orthographlc information such as letter shape Is processed In advance of the shift of attention, and that this results in the small benefit observed in the data without actualiy Influencling when the shift of attention wIII occur. Or, It may be that our concept of the attentional mechanism Involved in this process must be modifled somewhat, to assign some role to this accumulation of letter Information in determining when attention wIII shIft.

Morrison's model assumed that the tImIng of the shlft of attention was dependent on the encoding of the foveal 
word alone. This is not sufflclent to account for the current data unless we assume that the encoding of the foveal word, then the shlft of attention, and after that, partial encoding of parafoveal letter information has all taken place within the first $50 \mathrm{~ms}$ of the flxation, and that seems unilkely. It may be that a tentative decision to move the eyes is based on the accumulation of excltation from parafoveal letter Information, but that verlfication of the word currently beling processed has control as well. While the reader is processing the currently fixated word word, excltation from the letter information in the parafovea would be accumulating. When the current word is verlfied, and the excltation from the parafovea has reached threshold attention would shift to the next word to the right. This would trigger the programming of an eye movement to that word and at the same time inltiate the verlfication process for word $n+1$.

Thls type of attention mechanism is actualiy more consistent with the eye movement control mechanism described In the simpler target detection tasks, as well as giving a more complete account of reading phenemena. In the double step paradlgm (Becker \& Jurgens, 1979) subjects were asked to flxate a marked position and then move their eyes to a new target location when the parafoveal cue appeared. The pattern of results obtalned is Interpreted on the basls of the timing of the presentation of the parafoveal cues. If 
the shift of attention wwere dependent solely on the processing $t$ Ime for the foveal target then one would expect no effect of intertarget intervals. In the reading task processing the foveal word is a much more complex cognitive task than processing an isolated target in the double step task, and as such, its influence is much more apparent here. But, it seems that the role of the parafoveal information must be accounted for as well.

The model of saccade programming outlined by Morrison (1984) Indicates that more than one shlft of attention could occur in the course of a fixation, and that this second shift of attention would in turn InItlate the computation stage of programming another saccade. ThIs potentlal for rapld and efflclent utlilzation of parafoveal information gleaned from multiple shifts of spatial attention within a single fixation suggests that readers may attempt to extract useful Information from the parafoveal region to update their eye movement decisions far into the fixation. The data from Experiment 1 indlcated that saccades were longer when parafoveal Information was delayed $250 \mathrm{~ms}$ than when this information was never released. ThIs suggests that readers will continue to attend to the parafoveal region given that they have been unable to encode the Information that they need to program an eye movement, and that they are able to utlilze the late-arriving space information to modify the program for the subsequent saccade. The data 
also Indicate that saccade length decreases as delay Increases, suggesting that the later the relevant Information is avaliable the smaller the beneflt. This is consistent with the parallel programming model outlined earller.

\section{OutIIne for an Eye Guldance Model}

The present experiments were designed to Investigate the role of parafoveal letter and space information in the programming of saccades, and to investigate the role of attention in this process. These Issues arose from a model of eye movement control in reading that was outilned in the Introduction to this paper. The findings reported here make It necessary to modify that model somewhat.

The fact that readers were able to utllize parafoveal space information that became avallable $250 \mathrm{~ms}$ after the eye had come to rest In a new location is plausible if we assume a direct control model of eye guldance In whlch saccades can be programmed in paraliel. That is, the information recelved late in a fixation may be used to modify the subsequent saccade. It is Important to note that this extreme case would be a rare event in the course of normal reading, since flxations are typlcally less than $250 \mathrm{~ms}$ in duration. The more important polnt is that readers do continue to attend to the parafoveal reglon throughout the 
fixation; at least when the relevant information to program a saccade is delayed.

There were also critical findings regarding the role of parafoveal word boundary information in determining landing position. There are actualiy two decision processes occurring here. First the reader must declde which word wIII be flxated, and then, determine the optimal landing position within that word. Evidence from the present experlments suggests that letter information is used to determlne whether the reader will refixate the same word, move to the next word, or skip over the next word and saccade directly to word $n+2$. However, the landing position within the chosen word is computed primarliy on the basis of word length information.

The attentional mechanism of the model presented in the Introduction to this paper was too simplistic to account for the data we obtained. The model we would favor at this point involves two components, an encoding process and a verlfication process. As the foveal word is processed, excitation from parafoveal letter Information is accumulating. When foveal processing is complete, and excltation has reached threshold, attention shifts to word $n+1$ Initlating the computation of a new landing position based on word length.

Having defined the text characterlstics used to determine the Intended landing position, and an attention 
mechanicism sultable to account for the data obtalned in these experiments, the model is sufficlent to explain a number of important phenomena that have been reported in the eye movement IIterature, and to make some clear predictions for future work.

Before going further, let us recap the Important points of the model: a) foveal letter and parafoveal space Information are read in paraliel by Independent processes; b) space information is processed more rapldiy than letter Information; c) processing of letter information determines when attention will shlft; d) eye movements follow these shifts of attention; e) more than one shlft of attention can occur in the course of a single fixation; f) the landing position of a saccade can be computed before the decision to execute the saccade; g) processing of letter information Influences whlch word a reader wlll flxate next; $h$ ) the landing position within a word is computed on the basis of word length information.

Now, let us consider the simplest reading scenerio. Each word in the text is processed in sequence, when the encoding of word $n$ is complete, and the level of excltation from parafoveal letter Information has reached some threshold, an Internal attention mechanism shifts to the following word. This attention mechanism triggers an Instruction to execute an eye movement to that word. The parafoveal word boundary information has already been 
extracted, and the location of the next landing position Is computed based on word length.

In this scenerio all events occur In a serlal fashion; attention shlfts - eyes Jump attention shifts - eyes Jump. Landing position approximates the preferred vlewing location and the eyes land on every word.

However, reading is a complex process and there are numerous IntervenIng factors at work. The time to encode the currentiy fixated word wIII Influence when the eye movement is executed, and If processing the foveal word is difflcult the reader may require a second flxation on that word. At that polnt attention would shlft within word $n$, rather than to word $n+1$, word length of the currently flxated word is computed and a second landing position within that word is determIned, based again on word boundary Information. If this is the case then there should be a systematic pattern to second viewing positions on words that Is related to thelr length, much IIke the preferred viewing location of first fixations. This prediction of the model has yet to be tested.

We know from the data presented here that partial letter Information is extracted from parafoveal prevlew, and that space Information is processed more rapldiy than letter Information. Keeplng this In mind, suppose the reader encodes the currently flxated word and the threshold of excltation has been reached. Attention shifts to the next 
successlve word to the right, parafoveal space information has already been extracted, the length of word $n+1$ is calculated and a movement to the next word is programmed. At the same tIme, more parafoveal letter Information is processed; thls Information comblnes with highly constralned contextual Information, and word $n+1$ is verlfled. Attention then shifts to word $n+2$ and a movement is programmed to that word, cancelling the prevlous Instruction. The eye would then sklp over $n+1$ entirely and saccade directly to word $n+2$. It is important to note that this model is specifying a mechanlsm whereby visual Information about parafoveal letters Is fed "up" to comblne with contextual cues and that this results in the comblnatorlal power of the two factors. The model would not predlct that contextual factors would feed "down" to Influence how the parafoveal letters are percelved.

We can Imagine the same outcome given a silghtly different scenerlo as well. In thls case word $n+1$ is very short, the letter information is highly famlilar, and the syntactlc cues from the prevlous context suggest that this Is likely to be a function word. Here, context and letter Information, or context and space information could combine to make fixation on word $n+1$ unnecessary and the reader would saccade directly to $n+2$, sklpplng word $n+1$. Further research needs to be undertaken In order to determine exactly which factors influence the skipplng of function 
words.

The model wIII also explaln very short flxations and f Ixations on spaces between words. If a second attention shift occurs in the course of one fixation, but not qulckly enough to cancel the first, one of two things may happen depending on the $t$ ImIng between the two events. Elther the fIrst and second Instruction wIII be combined, resulting In a single saccade to an Intermedlate position, In whIch case the reader mlght $f$ Ixate the very end of word $n+1$ or the space between $n+1$ and $n+2$; or the first Instruction wIII not be cancelled, but a second Instruction wIII be Issued from the same fixation. Thus two eye movements wIII be programmed on fixation $n$ : the one terminating fixation $n$ and the one terminating fIxation $n+1$. If the second saccade programmed on flxation $n$ was programmed early enough, then Its execution could occur within the first $50 \mathrm{msec}$ of flxation $n+1$.

Thls model provides a clearer vlew of some of the baslc processes Involved in eye movement control whlch are pecullar to reading, whlle at the same time malntalning some conslstency with what is known of eye movement control mechanisms in other simpler tasks. There are stlll a multitude of questions to be addressed in the fleld of eye movement control. More work must be done to del Ineate the fundamental cognitive processes Involved In controlilng eye movements that wIII be conslstent across a varlety of tasks. 
Basic questions pertaining to eye movement control in reading are open to further investlgation as well. For Instance, why is it that some words are fixated twice in succession while others are not? is this an effect of I Inguistic processing, motor programming, or perceptual processing, or some combination of the above. it would seem that when we are able to understand thls phenomenon we WIII be one glant step closer to understanding eye movement control in reading. Hopefully, the groundwork lald down by thls model wIII be helpful in future research. 
A P P E N I X 


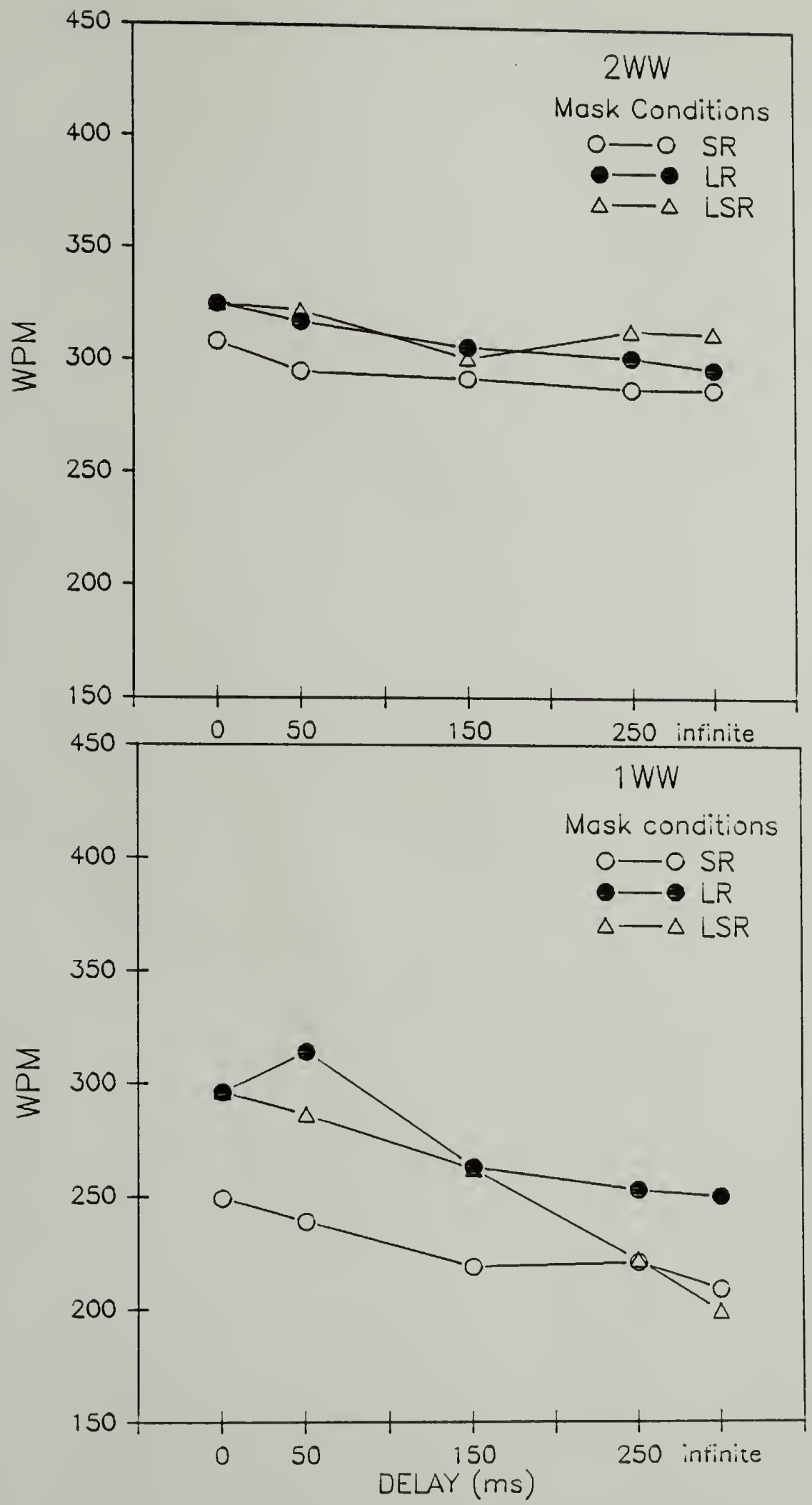

Figure 1 Reading Rate 


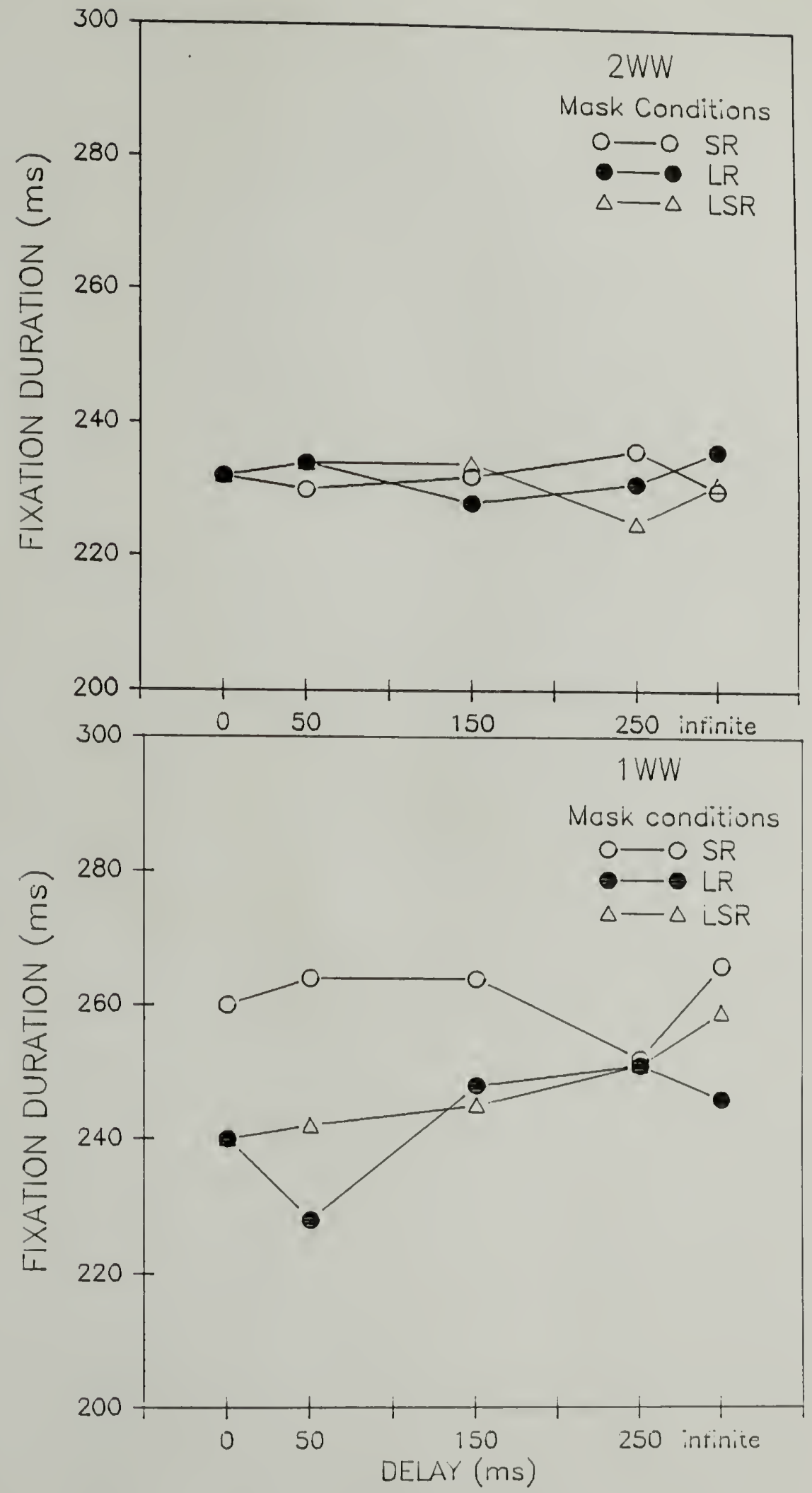

Figure 2 Fixation Duration 


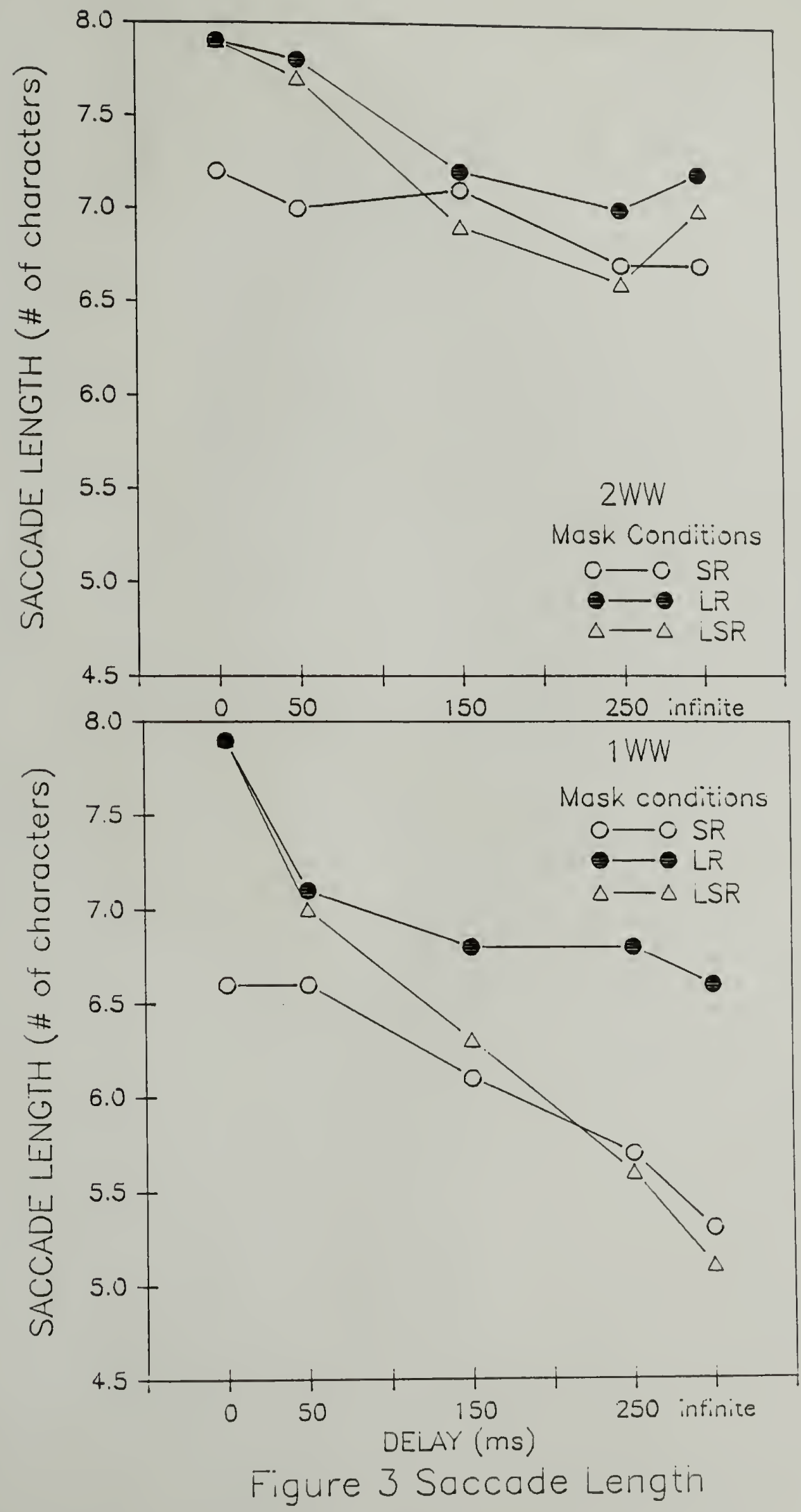




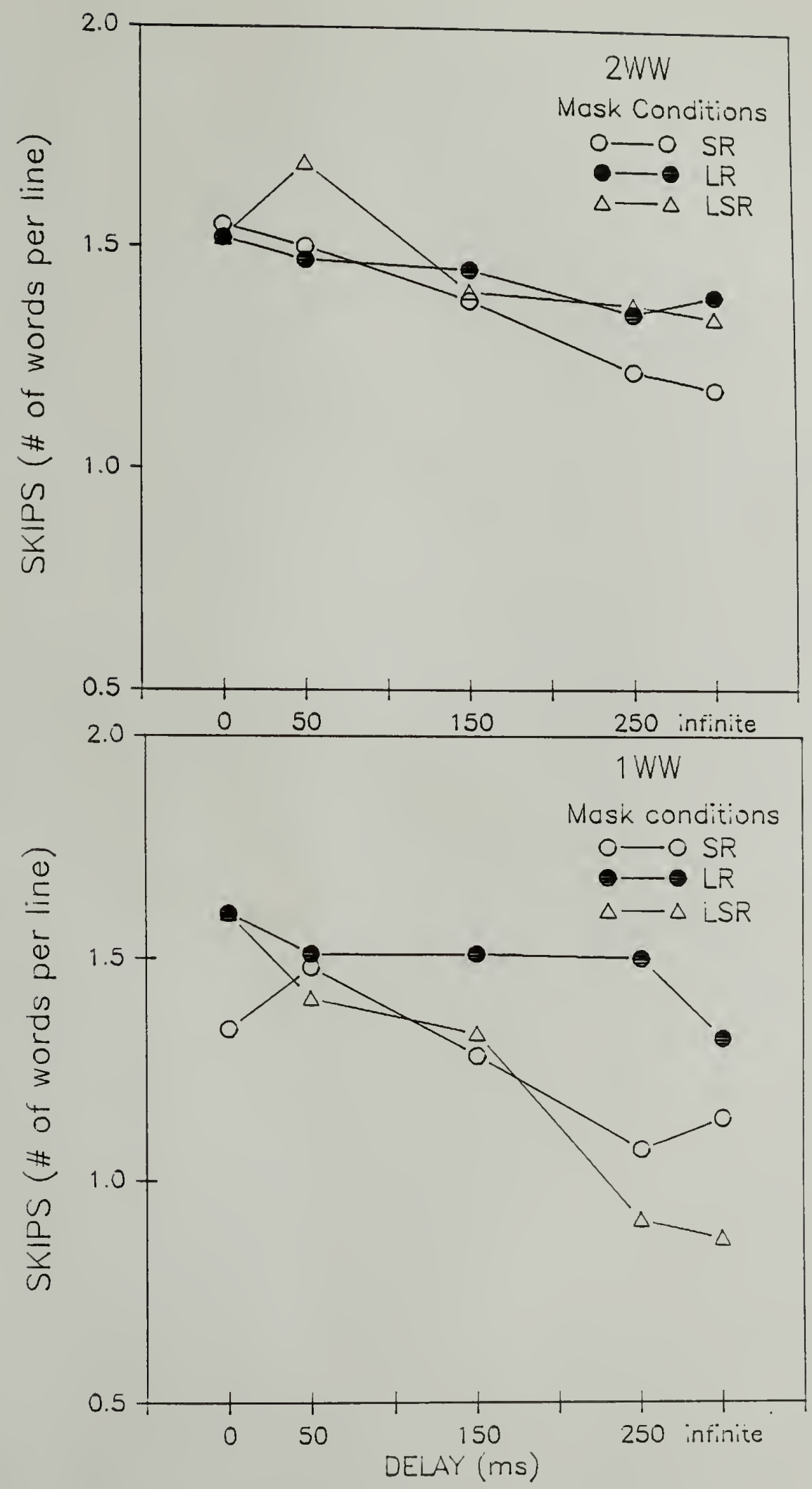

Figure 4 Word Skipping 


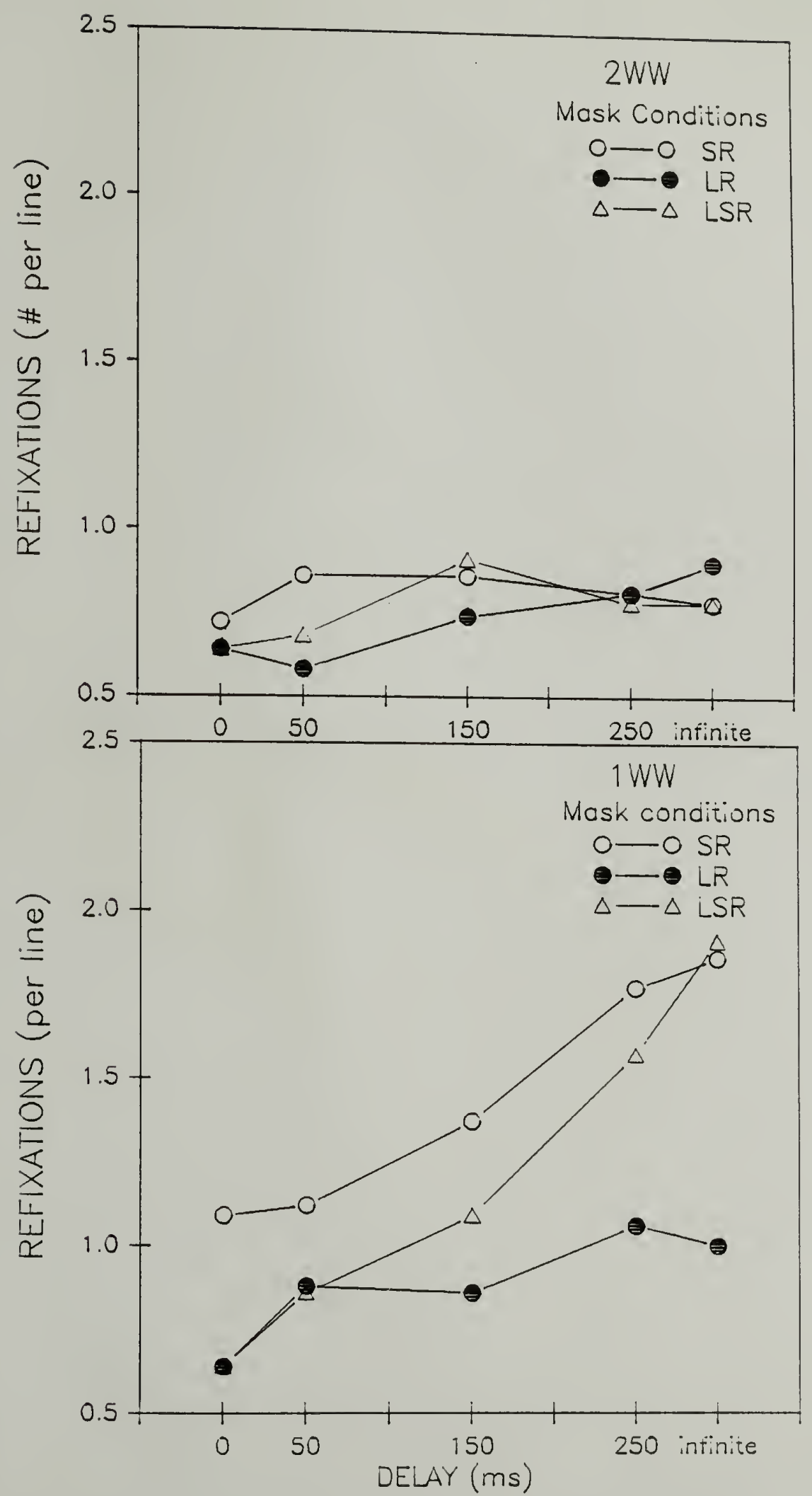

Figure 5 Consecutive Refixations 


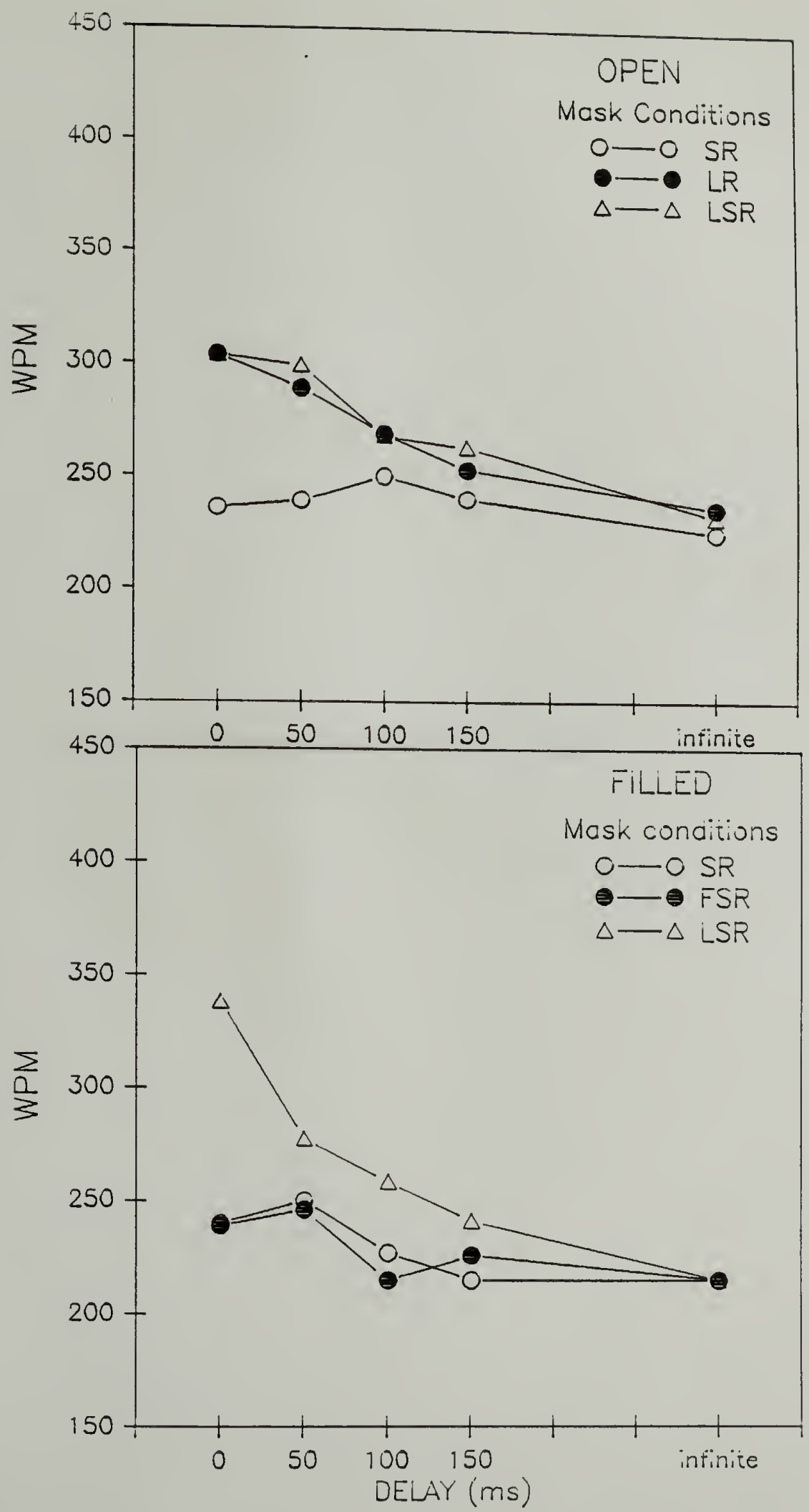

Figure 6 Reading Rate 


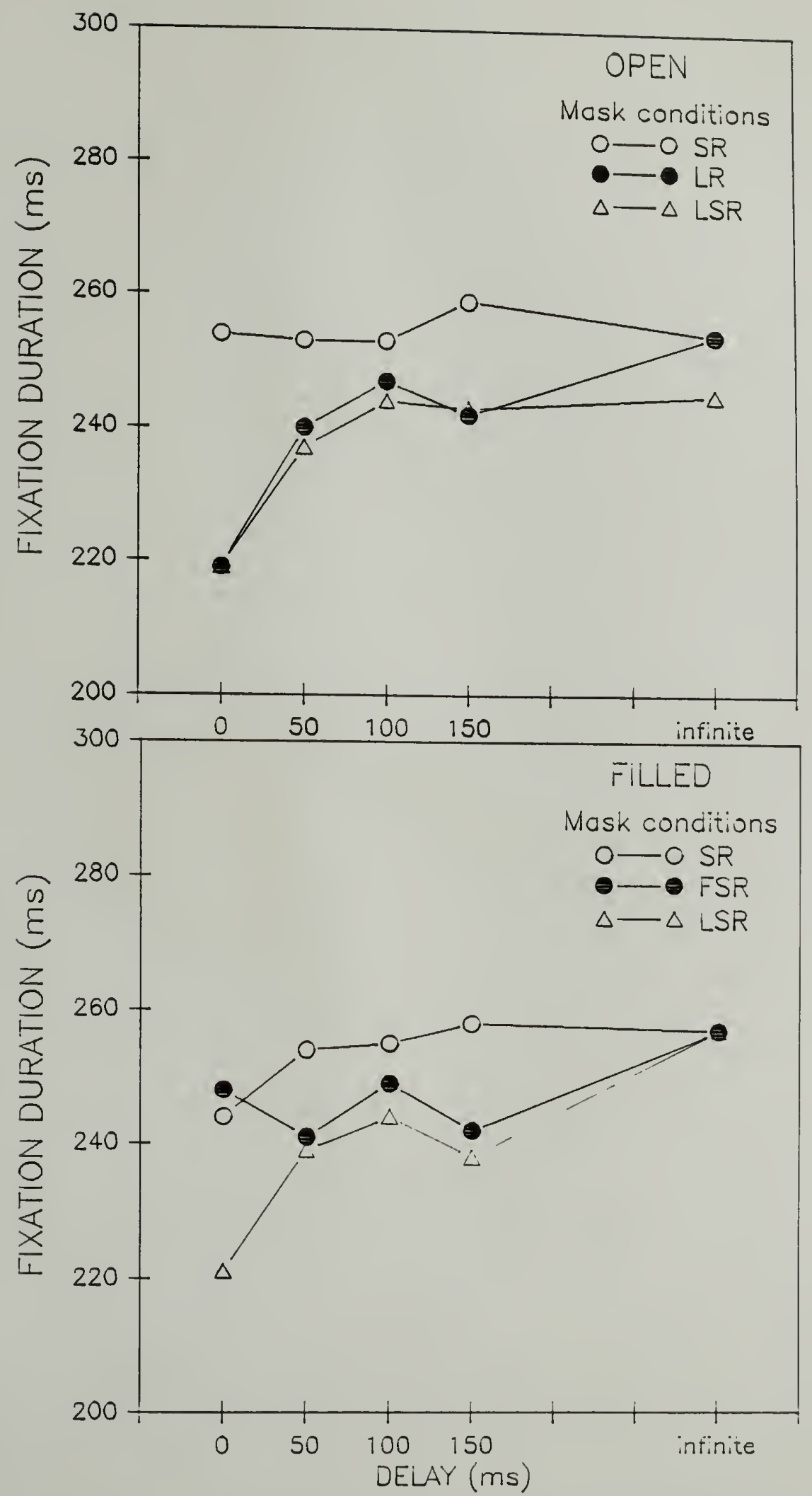

Figure 7 Fixation Duration 


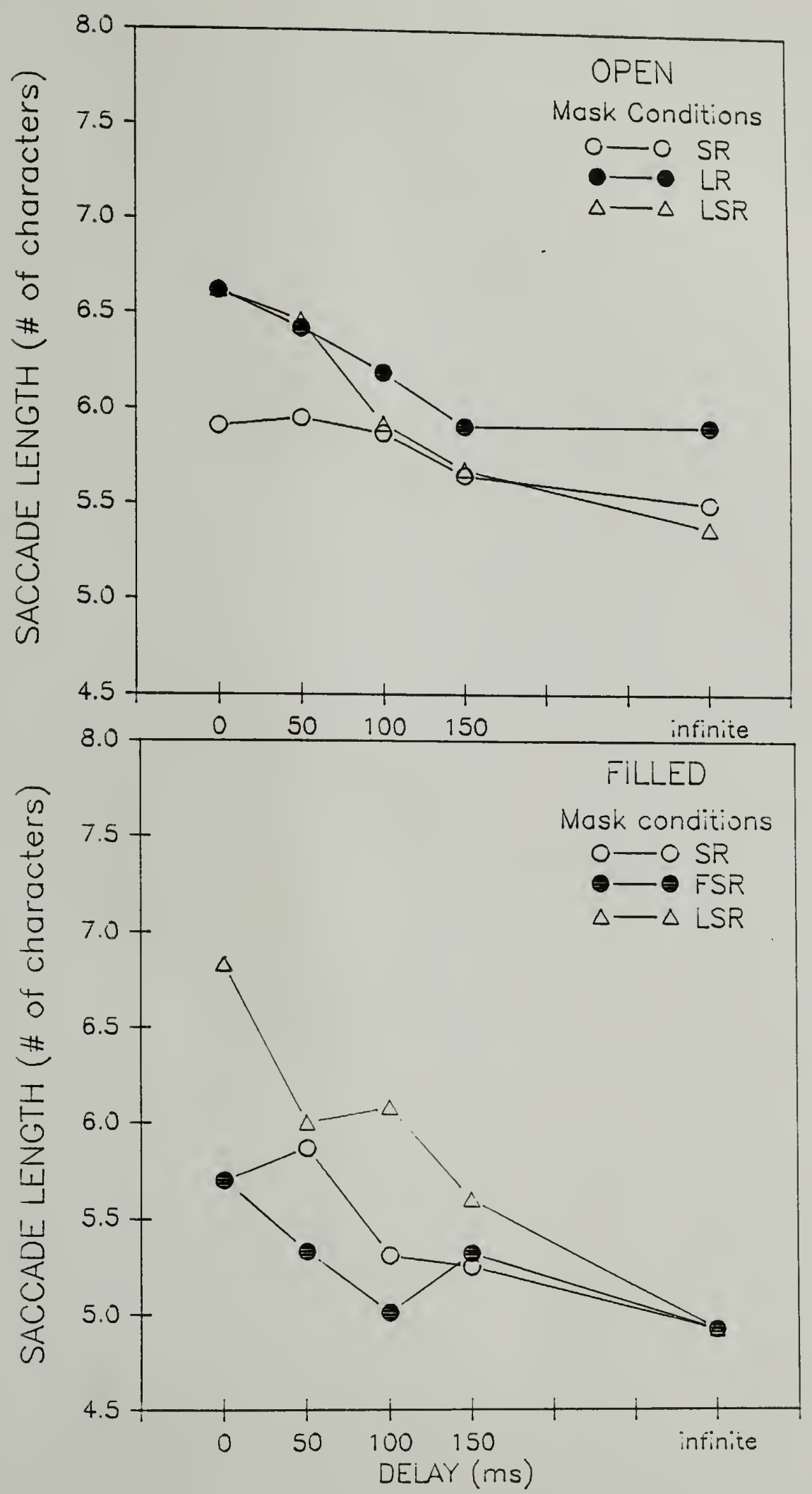

Figure 8 Saccade Length 


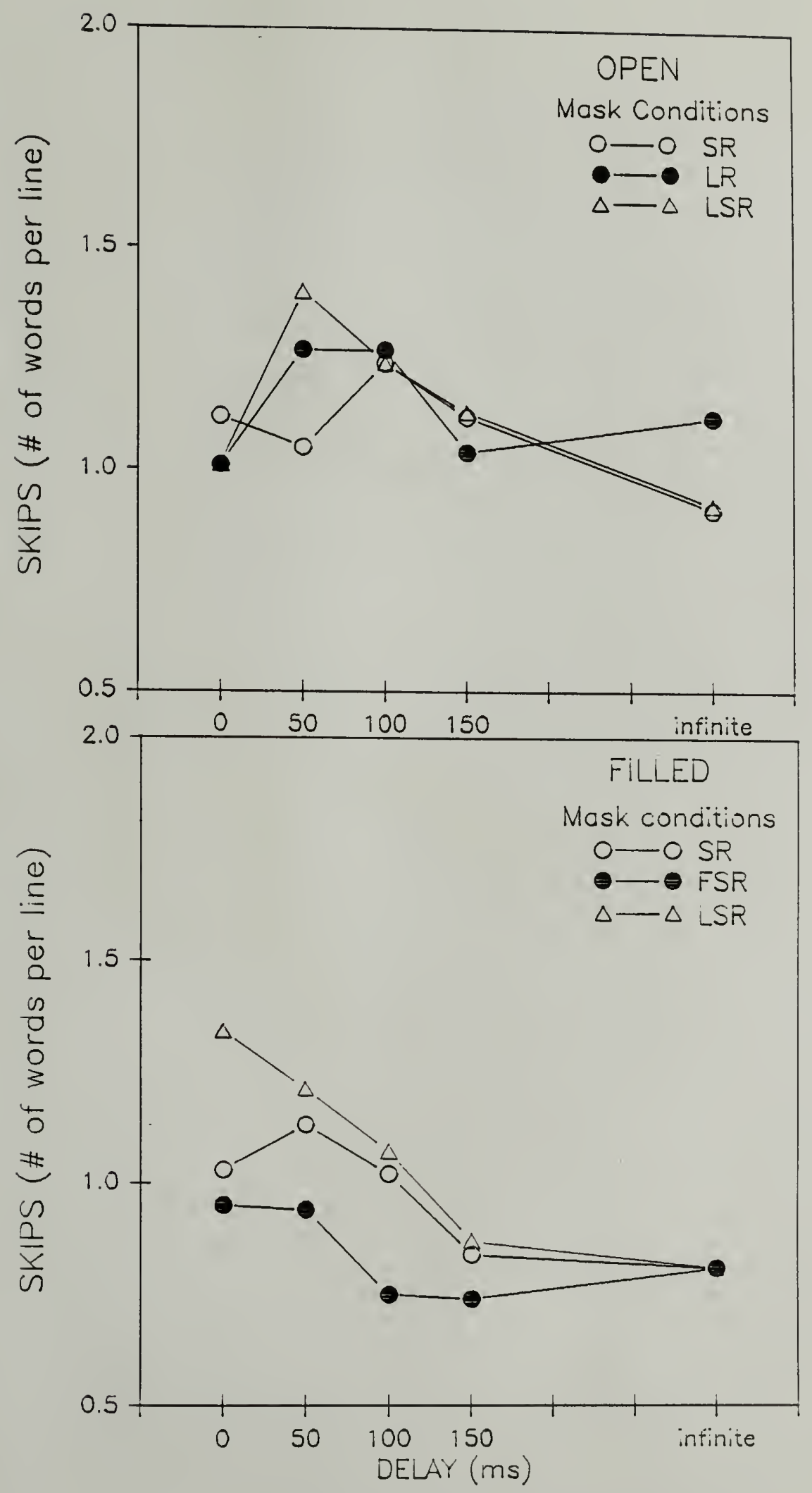

Figure 9 Word Skipping 

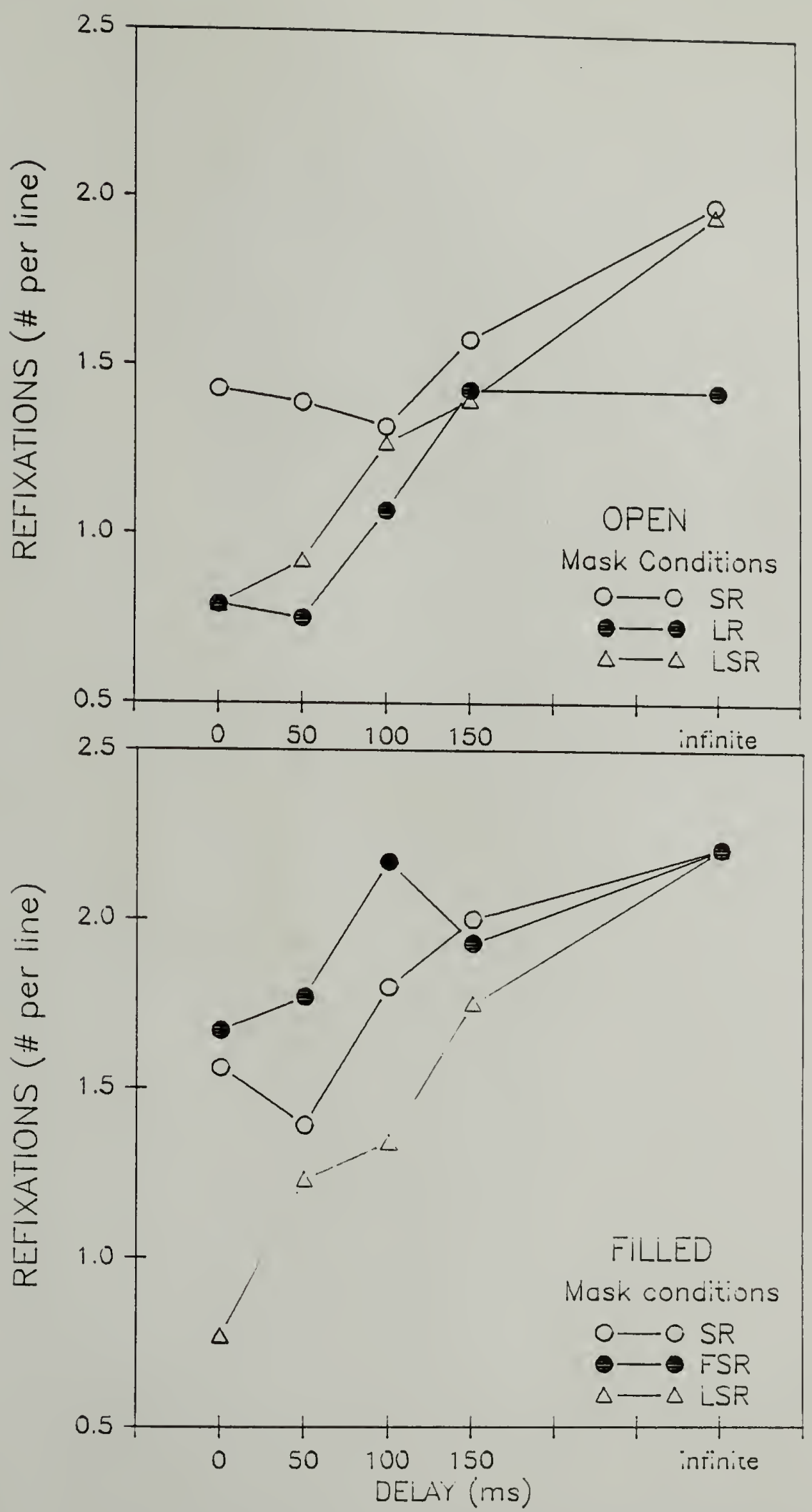

Figure 10 Consecutive Refixations 


\section{APPENDIX B}

Dalsy I It a candle In the hallway.

Shadows fllckered along the walls.

The sounds of the house overwhelmed her.

She moved gingerly toward the door.

Every step took Incredible effort.

The entrance seemed very far away.

The anticlpation became too great.

She raced to the safety of her bed.

A blcycle can simplify your IIfe.

It requires no Insurance or I lcense.

Malntenance is easy to manage.

You can learn to do your own repalrs.

The blke will take you where a car can't.

it brings a sense of freedom and control.

You travel swlftly under your own power.

And 1 t does not requlre a parking stlcker.

You can make thlngs disappear.

Confront the unwanted object directly.

Ralse your maglc wand over your head.

State your desire in a stern tone.

Tap the object smartly with your wand.

Turn on your heel and walk away.

Forget about the object forever.

Eventualiy the object will disappear.

Movie marathons are good for the soul. They are best carrled out on a sunday. Begin with a heart wrenching matinee. Now you WIII need some cheer Ing up. Proceed Immedlately to a l Ight comedy. By now it is time for a relaxing meal. After dinner a double feature is best. it is nice to end with old favorltes.

Yesterday Anne discovered a house fly. it was buzzIng around her window.

She told the famliy not to kll l it.

The fly became her personal frlend.

Anne called her frlend Ruth Buzzy.

She conversed with Ruth every day.

Ruth I Ived with us for several weeks.

Anne burled her under the IIlac bush.

Portland, Oregon acquired a new statue.

Portlandia is made of pounded copper.

She is as tall as a three story bullding. 
Only the statue of l lberty is taller.

A barge carrled her down the river.

She docked in the center of the clty.

A parade of cltizens followed excltedly.

She now slts overlook Ing her clty.

Mallory ran to her favorlte tree.

Woodcutters had felled the oak.

She was shocked and heart broken.

She turned to go, crylng bltter tears.

But somethling strange caught her eye.

It was a curling wisp of gray halr.

A polnted nose jutted from the tree trunk.

From deep withln came the wizard's volce.

Caroline was the first gIrl I klssed.

We were walklng back from school one day.

Somebody dared me to do lt, so I dld.

After that I did It every day.

A crack In the sldewalk marked the spot.

Then a nelghbor lady told my mother.

She solemnly forbade me to contlnue.

I could not understand why.

GrIzzly bears are nearly ext Inct.

Fur hunters slaughtered the bears.

Ranchers drove them off thelr ranges.

Bountles were offered for thelr hldes.

CIVIIIzation shrank the wIIderness.

Food became difflcult for them to find.

Small I Itters have added to the threat.

Something needs to be done to save them.

Auctions are often amazing to newcomers.

The auctloneer is a master entertalner.

He entertwines storles with buslness.

The merchandise is moved swiftly along.

Decislons are made on the moment.

A sense of antlcipation fllis the gallery.

Competition $r$ lses as the nlght goes on.

Everyone hopes to go home with a bargaln.

I remember vIsItIng my grandmother.

I made a splendld chocolate cake.

We drank alot of bourbon and talked.

Then we ate blg slabs of the cake.

We went to bed around ten $0^{\prime} \mathrm{clock}$.

It was ralning and we felt safe.

I made the same cake agaln last nlght.

lt dld not make me feel any safer.

The I It le cat loved the gas stove. 
It became her favorite winter spot.

She fit perfectiy over a burner.

The pllot I Ight made It a warm place.

The rlght rear burner was her own.

We seldom got a chance to use it.

The warm weather returned and she left.

sadiy, the stove became ours to use again.

Golng to market is a soclal event.

It is mostly the women who partlcipate.

Some of them walk many ml les to attend.

Many of them arrive before dawn.

They may be loaded down wlth produce.

Chlldren are carrled on their backs.

All of the women are eager to make a sale.

it is a time of news, gossip and laughter.

1985 was a year of varled disasters.

Our national debt was in the trillions.

CIVII avlation had its worst year ever.

There was an earthquake in Mexico.

But the volcano In Colombla was worse.

Third world starvation reached a new high.

Some say this was an adequate year.

The worse disasters were not our fault.

Voodoo is a Caribbean folk religion.

its rituals are quite pecullar.

People use the drum and the dance.

ThIs ritual Induces a state of trance.

The splrits can then enter the bodles.

What do people seek in all of this?

some seek a devine exlstence.

Others deslre resplte from their fears.

My sister called me yesterday.

She wanted her nose plerced.

No professlonal would do it for her.

So she had her housemate do it.

Two days later her nose became infected.

She had to remove the emerald stud.

She assures me lt is healing nicely.

The scar is hardly not lceable.

Have you ever mlsplaced your car?

Perhaps you need a carfinder keychain.

The tiny transmitter activates your horn.

It causes your headilights to flash.

All of this beglns from two blocks away.

Everyone wIIl know where your car Is.

ThIs wIII cause you publlc embarassment.

You won't forget where you parked again. 
The story is an eplc romance.

It begins in the forest of Bohemia.

The hero is a Janitor with a bottle.

The bottle is anclent blue alabaster.

It shows the lmage of a goat-horned god.

It contalns the essence of the universe.

The Ilquid is leaklng from the bottle.

There is only a drop or two left.

Black-necked stlits are small shore blrds. They are only $s \mid x$ Inches tall at maturlty.

They often nest near shallow ponds.

Thelr reaction to flood danger is unusual.

The male and female work together.

The male brings leaves and stlcks.

The frantic female elevates the nest.

Sometimes the nest is ralsed four inches.

The urban apartment barbeque was not easy.

Our frlend owned a very small hlbachl.

We used it to gr|ll on the wIndows III.

But people passing by complained.

They were afrald of hot falling coals.

Disposing of these coals was more trouble.

Even after several hours they can ignlte.

The flaming dumpster was proof of this.

What was so speclal about last year?

The inventor of twinkles dled.

The supor bowl was the most watched show.

Eleven Amer lcans were accused of spylng.

Coke brought back the classlc coke.

Our oldest presldent began a second term.

A guru lost elghty-two rolis royces.

History can be a very mundane toplc.

Running in winter weather is difficult.

Safe routes are not easy to find.

Forest tralis way have treacherous ice.

it is very easy to sIIp and fall.

The road has unlque dangers of Its own.

Cars splash huge fans of filthy siush.

Winter driver visibility is often poor.

The dedicated runner wlll strlve to adapt.

My mother is not a baker.

Christmas goodles are a famliy joke.

We use her frultcakes as doorstops.

They are good at keeping doors open.

As food they are hard to swallow.

But every year she tries again. 
And whlle they bake we remlnlsce.

Famliy traditions make holldays speclal.

Donna dreamed of rlding in a blimp.

The blimp came to town once a year.

They never took on public passengers.

But Donna always went to watch.

Every year she got a little blt braver.

She conversed with the people in charge.

They learned of her long standing deslre.

sworn to secrecy, she was taken aboard.

He looked I Ike a common face in the crowd.

But he was carrying a loaded handgun.

For black teenagers hassled $\mathrm{hlm}$.

They wanted hls money, and he shot them.

One of the boys is now paralyzed for IIfe.

Goetz had acted out an urban fantasy.

He enjoyed a brlef whIrl as a folk hero.

Then he was Indlcted for attempted murder.

Kate always went to the library to study.

It was Impossible to study in her room.

She shared $1 t$ with two other people.

They trled not to disturb her.

But she was easliy distracted.

At the llbrary Kate found seciusion.

She went directly to an Isolated corner.

In the qulet, her concentration returned.

Pan was a nolsy, merry, earth god.

He was part goat and part man.

All the woodlands were $h$ is home.

He was a wonderful muslclan.

He wandered the forests playlng $h / s$ reeds.

Unknown sounds were attrlbuted to Pan.

His mysterlous muslc frightened travelers.

Thls is where the word panlc comes from.

Karen hated to do her laundry.

She did not I Ike golng to the laundramat.

People there never spoke to each other.

The steamy air was hard to breathe.

The washling machines were dingy and ugly.

Karen avolded going as long as possible.

But she had no clean clothes left.

Dolng laundry was no longer a cholce. 


\section{APPENDIX C}

Please help a toad across the road.

Thls Is the British toad lobby's slogan.

volunteers wear galoshes and ralncoats.

They are armed wIth palis and flashlights.

They help mlgrating toads over busy roads.

Toad escort is hlgh pressure employment.

Ralny nlghts around eleven are crltical.

Many toads are kll led at pub closing time.

I have Imaglned returnIng here many times.

It is sister Francls who opens the door.

She has only three teeth left now.

Two are on the top and one on the bottom.

Her eyes are so red, and so blank.

She has the look of a graet rabblt.

Twenty years ago I left this convent.

Thls dream reminds me of why I left.

A small group went fishing of the coast. Suddenly the sea churned about thelr boat. A large school of whales surrounded them. The men shut off thelr motors and drlfted. They didn't want to disturb the creatures.

For flve hours the whales stayed close.

Sometimes they gently nudged the boat.

But they showed no signs of aggression.

Howard was driving along the hlghway.

Suddenly hls rlght front tire blew out. HIs car swerved wlidly off the road.

He knocked down a large power pole.

The wlres fell across the rall road tracks.

Thls short clrculted the town's power.

The power surge blew up a gas station.

Howard suffered a badly spralned wrlst.

Poland exports 100 tons of halr annually.

They send It all to West Germany.

In return, they recelve barber equipment.

We may assume $t$ Is is to cut more halr.

What are the German's dolng with that halr?

Maybe they use lt to stuff pin cusholns.

or is the entire country naturally bald?

That much halr would make alot of wigs.

How do marsh wrens attract thelr mates?

It can't be their flamboyant appearance.

They are Inconsplcuous, small brown blrds.

It Isn't through monogamous commlttment.

The males take many mates each season. 
It must be their amazlng singlng ablilty. Males sing hundreds of different songs. The better singers attract more mates.

Some Inventions took real creativity. Fuzzy dashboard dlce are a good example. Who ever thought fuzzy dlce would sell? Where do ldeas I Ike thls come from? Some come from Leomlnster, Massachusetts. It is the home of plnk plastic flamingos.

In 1985 a half mlilion flamingos sold.

Is this what they call Yankee Ingenulty?

KIm was sIx when she read about the Incas. They played a game sImllar to basketball. But It had a very different ending. The winneers were sacrlflced to the gods. Thls sounded l Ike an Interesting concept. What If her brother was on the other team? She would feel terrlble If Jack dled. Then agaln, he wouldn't like to lose.

Goats are famous for thelr appetites. Every old farmer has a good goat story. Goats can and WIII eat almost anythIng. At least that is how the story is told. In one such story the goat drank gasoline. That was okay, unt I he ate the matches. Even goats can't stomach that comblnation. Thls story IIterally ended with a bang.

Do you have a perspiration problem? Here's something that wIIl end your woes. Thls product stops sweat for six weeks. It's a heavy sweater's answer to wetness. stop costly underarm, hand or foot sweat. Short electronlc treatment really works. Reccommended by dermatologlsts everywhere. send for your free information now.

Tom Anderson was a courageous fellow. But hls courage cost $\mathrm{hlm}$ some money. He saw a robber hold up a man in the road. Tom made a dive for the crook's gun. He knocked It out of the robber"s hand. But now the victim plcked up the gun. He put the weapon to poor Tom's rlbs. The supposed vitcim left with Tom's money.

Flowers were a staple of the MIddle Ages. They were valued for thelr perfume. Nosegays were hung to mask odors. 
Flowers were also used to flavor food. Hawthornes or primroses were put In soups. Vlolet petals were consldered dellcacles. Europeans scattered marlgolds on any food. Flowers provlded $f$ lavor and visual appeal.

Dwlght Elsenhower was a ml I Itary man. That is where he learned to use a phone. After that he moved to the Whlte House.

As Presldent he used the phone frequently. He called all telephone operators central. Central did all hls dialing for $\mathrm{hlm}$. He left the Whlte House a helpless man. He had never learned to dlal a telephone.

Are you up on your Tarzan trivla? What do you know about Tarzan yells? Frank Merrll l gave the flrst human yell. Johnny Welsmuller's movle yell was dubbed. It's a $\mathrm{mlx}$ of vlolin, hyena, and camel. Ron Ely used the same yell on television. Carol Burnett brought back the human cali. It was a regular gag rout ine on her show

A father and son went out explor Ing. They were lookling at an excavation slte. A sudden lands I lde caught the boy. He was half burled; more dirt was falling. The father threw $\mathrm{hlm}$ a garden hose. The boy breathed two hours with the hose. Finally the rescue team arrlved. The father had saved hIs son's IIfe.

A sweater telis a woman's personallty. Fashlon researchers say $1 t^{\prime} s$ true. Sensual women wear low cut necklines. Mature women prefer hlp length sweaters. Easy golng women own dark bulky sweaters. Medlum bulkles belong to loglcal women. No sweater Indlcates no character?

Ten vlctims were condemned to death.

They were I Ined up before a firling squad. Just before the vol ley roared one falnted. He fell rlght before the other victims. The executloners notlced nothing of this. They left the bodles where they lay. Later the man regalned consclousness. He had difflculty belleving he was allve.

How Important is m I I tary muslc?

Sousa lovers take a front row seat. 
Reagan's administration says It's speclal. The new budget proposal demonstrates thls. MIIItary bands recelve generous support. National endowment of the arts gets less. The marchlng band is the art of 1987. So pull up a curb and enjoy the parade.

A vaudeville actor had to traln chlmps. One day he went into the forest wIth them. He didn't come back, but hls chlmps did. Pollce found them chatterling excltedly. They led the pollce to the slaln actor. Upon returning to town they saw two men. The chlmps attacked the men wlidly.

The chlmps had ldentifled the murderers.

Here's how to marry a man of your cholce.

Do not use excesslve perfume.

Do use enough soap and wear t-shlrts.

Remove food particles between your teeth.

Do not chew gum and smoke simultaneously.

If you need to pass gas face $\mathrm{h} / \mathrm{m}$.

Does thls sound I Ike a comedy rout Ine?

It is a serlous new best selling book.

Stanley worked at a Nuclear power plant.

But hls presence set off radlation alarms.

Federal tests were conducted on hls home.

They discovered very hlgh radon levels. Radon Is a gas emltted by decaying radium. The famliy health rlsk was extreme. It was like smoklng 2,700 clgarettes dally. Action is beling taken to help the famliy.

Brltish anlmal lovers have gone batty. BIrd feeders are belng abandoned. Bat boxes are taking thelr place.

FIve thousand people subscr Ibe to Batnews. It is now a crime to kll l or Injure a bat. It's Il legal to keep bats from golng home. There is one exception to the new law. One can tend an injured bat and let it go.

It began a month after June dled.

It was hls hands that made hlm drink.

They remembered too many things.

Thlngs he had forced $h / s \mathrm{~m} /$ nd away from.

HIs hands would not stay stlll.

They did things when he wasn't looklng.

They tipped one beer after another.

And stlli hls hands remembered June. 
No one wants to die in a terrorlst attack.

Do you have valld cause for concern?

If you bathe in a bathtub maybe not.

You are much more likely to dle in a tub.

Do you talk on the phone frequently?

Thousands dle of phone injurles annually.

Are you single female and over forty?

Terror ism is more likely than marriage.

A gentieman from Chlcago went fiy fishling.

The first cast he attempted missed.

He fllpped $h$ ls I Ine back for a second try.

The I I ne caught over his shoulder.

He turned expecting to untangle his IIne.

There stood a bear with a hook in Its ear.

The fisherman dropped $h l s$ I Ine and $r a n$.

We have yet to hear what the bear dld.

Someone is playling a trick on me.

I keep writing these little stories.

And then I sit back and count them.

1 find that 1 am short one story.

So 1 write another and count again.

I scribble some more and check again.

The pattern keeps repeating itself.

I wonder if $\mid$ wIII ever be finIshed.

The word yupple doesn't exlst for some.

One third of Amerlca has never heard it.

Thls ralses some puzzling questions.

Does this mean not everyone reads Newsweek?

But then what do they read instead?

Where do these nalve individuals i ive?

What word do they use to Indlcate yupple?

Are they yupples themselves?

Life with father was always a challenge.

He was a flercely self rellant man.

And he demanded no less of hls famliy.

Especlally us, we are hls two young sons.

We would have followed $\mathrm{hlm}$ anywhere.

Here we are in a steaming jungle.

No more rotten clvilization, he says.

We are golng to bulld a perfect paradise. 


\section{REFERENCES}

Balota, D.A., Pollatsek, A. \& Rayner, K. (1985). The Interaction of contextual constralnts and parafoveal visual information in reading. Psychology, 17, 364-390.

\section{CognItive}

Becker, W., \& Jurgens, R. (1979). An analysis of the saccadlc system by means of double-step stimuli. VIsIon Research, 19, 967-983.

Carpenter, P.A. \& Just, M., (1983). What your eyes do whlle your $\mathrm{m}$ Ind is reading. In: K. Rayner (Ed.) Eye

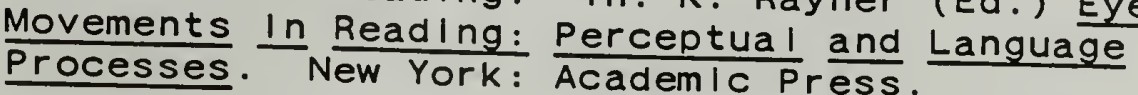

Clark, M.R. (1975). A two-dimenslonal Purkinje eye tracker. Behavlor Research Methods \& Instrumentation, $7, \frac{\text {, }}{215-219}$.

Cornsweet, T.N. \& Crane, H.D. (1973). Accurate twodimensional eye tracker using first and fourth Purk InJe Images. Journal of the Opt lcal Soclety of
Amer Ica, 63, 921-930.

Engel, F.L. (1971). VIsual consplculty, dIrected attention and retinal locus. VIsIon Research, 11, 563-576.

EhrIICh, S.F. \& Rayner, K. (1981). Contextual effects on word perception and eye movements durling reading. Journal of Verbal LearnIng and Verbal Behavior, 20 ,

Hogaboam, T.W. (1983). Reading patterns in eye movement data. In K. Rayner (Ed.), Eye Movements In Reading: Perceptual and Language Processes. New York: AcademIC Press.

Ikeda, M., \& Salda, S. (1978). Span of recognltion In reading. VIslon Research, 18, 83-88.

Inhoff, A.W. \& Rayner, K. (1987). Parafoveal word processing during fixations in reading: effects of word frequency. Perception \& Psychophyslcs, $40,431-$ 439 .

Kaufman, L. \& Rlchards, W. (1969). Spontaneous flxation tendencles for $v i s u a l$ forms. Perception \& Psychophysles, $\underline{5}$, 85-88. 
LIma, S.D. (1987). Morphologlcal analysis In sentence reading. Journal of Memory and Language, 26, 84-99.

Mcconkle, G.W. (1983). On the role and control of eye movements In reading. In P.A. Kolers, M.E. Wrolstad, New York: Academlc Press.

Mcconkle, G.W. \& Rayner, K. (1975). The span of the effective stimulus during a fIxation In reading. Perception \& Psychophys ICs, 17, 578-586.

Morrison, R.E., (1984). Manipulation of stimulus onset delay in reading: evidence for parallel programming of saccades. Journal of Experimental Psychology: Human Percept ion and Performance, 10, $\frac{1067-682 .}{66}$

O'Regan, J.K. (1979). Eye Guldance In readIng: Evldence for the lingulstic control hypothesis. Perception \& Psychophysles, 25, 501-9.

O'Regan, J.K. (1980). The control of saccade slze and fixation duration in reading: The $\mid$ ImIts of I Ingulstic control. Perception \& Psychophyslcs, 28, 112-117.

O'Regan, J.K. (1981). The "convenlent vlewlng posltion" hypothesIs. In D.F. FIsher, R.A. Monty, and J.W. Senders (Eds.), Eye movements: Cognlt lon and visual perceptIon. HIIIsdale, N.J.: Er Ibaum.

O'Regan, J.K. \& Levy-Schoen, A. (1987). Eye movement strategy and tactlcs in word recognltion and reading. In M. Coltheart (Ed.), Attentlon and Performance 12 . London: Er I baum.

Pollatsek, A., \& Rayner, K. (1982). Eye movement control In reading: The role of word boundarles. Journal of Exper Imental Psychology: Human Perception and Performance, 8 , 817-833.

Rayner, K., (1975). The perceptual span and perlpheral cues In reading. Cognlt Ive Psychology, $\underline{7}, 65-81$.

Rayner, K., (1979). Eye guldance In ReadIng: FIxation locatlons within words. Perceptlon, 8, 21-30.

Rayner, K., Inhoff, A.W., MorrIson, R.E., SIowlaczek, M.L. \& Bertera, J.H. (1981). Masking of foveal and parafoveal vision during eye flxations in reading. Journal of Exper Imental Pschology: Human Percept Ion and Performance, $\underline{7}, 167-179$. 
Rayner, K. \& McConkle, G.W. (1976). What guldes a reader's eye movements? VIsion Research, 16, 829-837.

Rayner, K. \& McConkle, G.W. (1977). Perceptual processes in reading: The perceptual spans. In A. Reber \& D.

Scarborough (Eds.), Toward a Pschology of Reading.

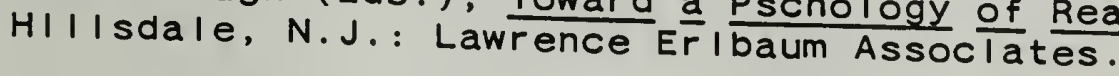

Rayner, K., \& Pollatsek, A., (1981). Eye movement control durling reading: Evldence for direct control. Quarterly Journal of Experimental Psychology, 33A.

Rayner, K., Wel I, A.D., \& Pollatsek, A. (1980). Asymmetry of the effectlve visual fleld durling reading. Perception \& Psychophyslcs, 27, 537-544. 



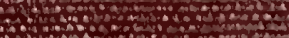

atio

$\ldots$ $x+1.10$

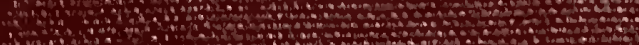

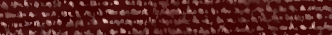
ard

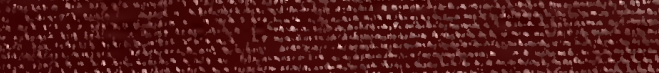

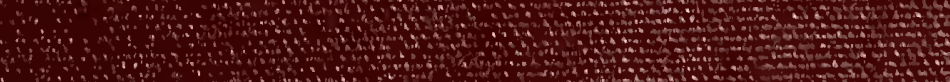

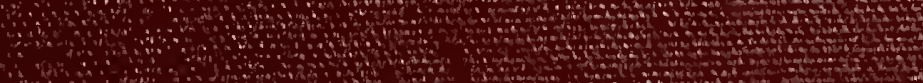

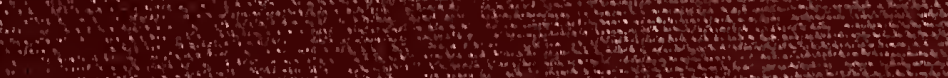

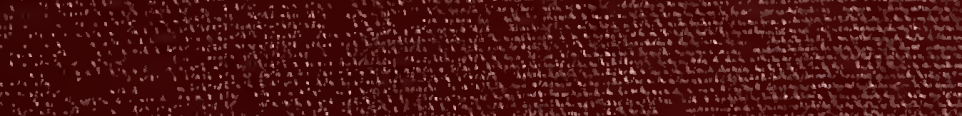
m.

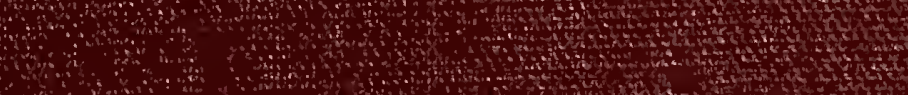

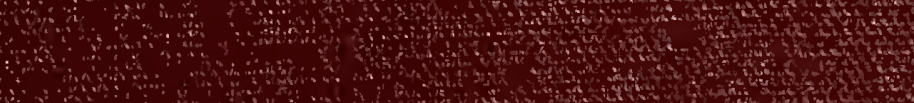

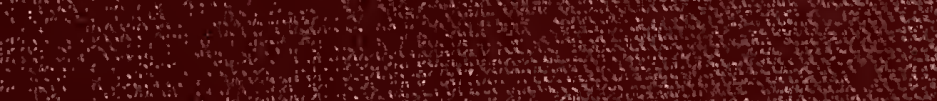

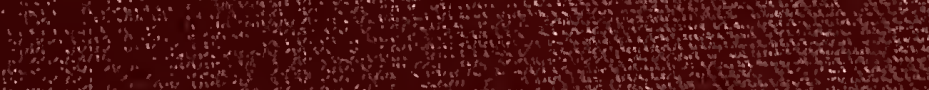

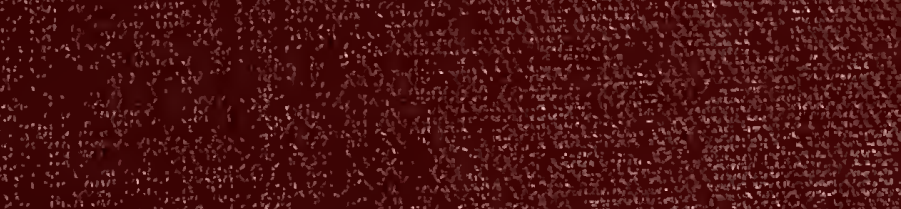

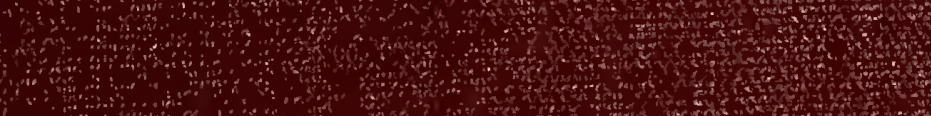

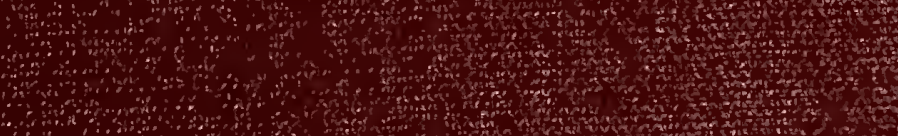

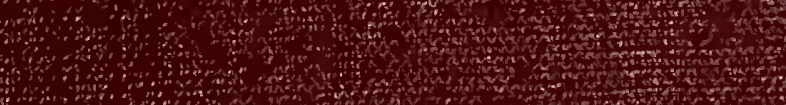

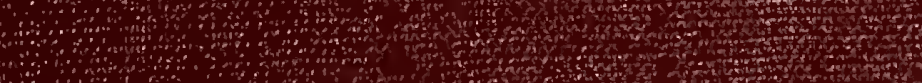
W

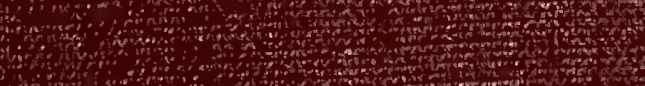

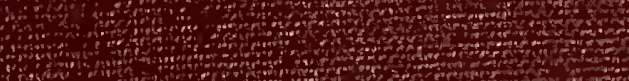

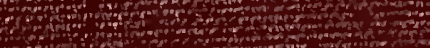

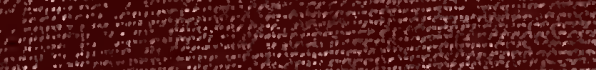
IN, n and

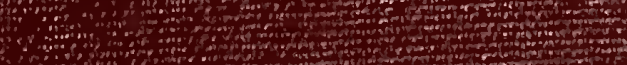

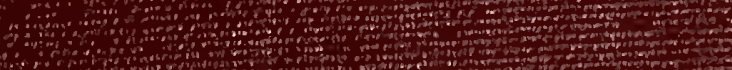
and 8 4270 .

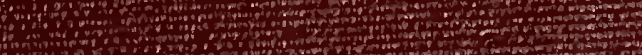

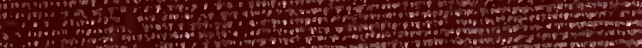
ming 